\section{Offshoring, job satisfaction and job insecurity}

\author{
Santiago Budría and Juliette Milgram Baleix
}

\begin{abstract}
This paper investigates the effects of offshoring on individual job satisfaction and perceived risk of job loss. The authors merge microdata from the German Socio-economic Panel dataset (SOEP) with indicators of insertion in global value chains at the industry level for the period 2000-2013. They test two hypotheses. First, the authors investigate whether workers in industries with higher offshoring intensity report lower job satisfaction and/or are more prone to be unsecure at their jobs. Second, they test whether these effects differ among four categories of collars. Their findings indicate that offshoring is associated with lower job satisfaction. The results are also indicative of some heterogeneity in the offshoring effect, with high skilled white-collar workers being mostly unaffected by offshoring and low skilled blue-collar workers showing the largest negative effects. Discriminating between manufacturing and services activities, the authors find that the extent of heterogeneity and the offshoring effect is relatively larger in manufacturing industries. They also find that the effect of offshoring intensity upon job satisfaction is more negative and significant in periods of economic decline. Finally, the results show that offshoring is not significantly related with job insecurity, a result that applies to all workers' categories. Still, in a period of economic decline job insecurity may increase when the offshoring intensity rises.

(Published in Special Issue Recent developments in international economics)
\end{abstract}

JEL I31 F6

Keywords Job satisfaction; job insecurity; offshoring; Germany

\section{Authors}

Santiago Budría, « University Antonio de Nebrija, Madrid, Spain; Centro de Estudos de Economia Aplicada do Atlântico (CEEAplA), University of Madeira and University of Açores, Portugal; IZA Institute for Labor Economics, Bonn, Germany, sbudria@nebrija.es

Juliette Milgram Baleix, University of Granada, Granada, Spain

Citation Santiago Budría and Juliette Milgram Baleix (2020). Offshoring, job satisfaction and job insecurity. Economics: The Open-Access, Open-Assessment EJournal, 14 (2020-23): 1-32. http://dx.doi.org/10.5018/economics-ejournal.ja.2020-23

Received November 1, 2019 Published as Economics Discussion Paper November 22, 2019 Revised June 2, 2020 Accepted June 8, 2020 Published July 2, 2020 


\section{Introduction}

The Great Recession and rise of China in World Trade has raised the debate about the impact of trade on wages and employment, in particular in the US (Autor et al., 2013; Feenstra et al., 2019) but also in Europe. Globalization is frequently blamed for fuelling wage inequality, and a flourishing and promising literature intends to gauge the role of trade on different aspects of labour markets.

This paper focusses on a specific aspect of trade globalization, offshoring, and on two specific labour market outcomes: individual job satisfaction and perceived job insecurity. The paper investigates two hypotheses. First, we wonder whether offshoring intensity affects job satisfaction and perceived job insecurity. Second, the paper tests whether the association between job satisfaction and perceived job insecurity differs among collars. To that purpose, we merge micro data from the 2000-2013 waves of the German Socioeconomic Panel (GSOEP) with information from the Trade in Value Added (TiVA) database from the OCDE. We use industry as matching criterion and therefore combine detailed individual information on personal and job characteristics with the offshoring intensity within the industry where the individual works. This allows us to estimate a set of job satisfaction and job insecurity equations controlling for individual fixed effects and a number of socio-economic and job level characteristics.

Empirical studies have drawn in recent years a complex picture of the effect of the internationalisation process on labour markets. Actually, it seems more complicated than ever to identify globalisation's winners and losers (Crozet and Orifice, 2017 for a survey) and to isolate all the possible links between trade and labour markets. While most research to date has focussed on the impact of globalization on wages and inequality (Crinó, 2009, for a review), only a few papers have examined the effects of the internalization process on job insecurity and none has examined its effects on job satisfaction. The first contribution of this paper is precisely to fill this gap. Job satisfaction is an important component of subjective well-being (Van Praag and Ferrer-i-Carbonell, 2008) and is also related to a number of economic outcomes, including labour productivity and lower absenteeism (Oswald et al. 2015). However, the literature to date has remained silent about the effects of firm internationalization on job satisfaction. ${ }^{1}$ In this paper we hypothesise that even if offshoring does not have direct effects on wages, it can lower workers' job satisfaction by worsening their job conditions, bargaining power and turnover rates.

Job insecurity refers to perceptions of risk and forward-looking labour outcomes. The distinction between job insecurity and previous literature focusing on wages and employment transitions relies on the notion that future risks can be more damaging to people's life than real events. In fact, concerns about job loss could be as detrimental, if not more, than the actual occurrence of job loss (Burgard et al., 2009). Moreover, the perceived rather than the formal job insecurity is what matters for workers' well-being (Jahn, 2015). Apart from this, due to globalisation and increasing competition, European labour markets have experienced an increasing flexibility, and workers at all levels of the occupational hierarchy have seen their

1 The closest question analyzed is whether life satisfaction is positively associated with globalization, broadly defined as a concept including economic, social and political aspects (Khun et al., 2015). 
future threatened (László et al., 2010). Therefore, the concepts of job and economic perceived insecurity have acquired their own status in the economics literature and are now studied as stand-alone subject (Rohde et al., 2017). Earlier studies examining the links between offshoring and job risk are based on objective unemployment hazards (Görg and Görlich, 2012 and 2015 for studies using the same dataset as we do). As far as we know Geishecker et al (2012) is the only study that focusses on perceived job fears. ${ }^{2}$ Our interest in subjective appraisals relies on the fact that individual wellbeing is more dependent on ex-ante individual perceptions than on ex-ante objective hazards. Moreover, what arguably matters most in terms of public support for free trade or wage bargaining are subjective concerns about job security. The underlying hypothesis is that in a context of increasing vertical fragmentation of production at the world level, trade in intermediate goods may imply more subtle mobility of workers within and among sectors, and ultimately can impact the perception of workers regarding the stability of their jobs.

The second contribution of this study is to test for heterogeneous effects among groups of workers. Indeed, the associations between offshoring and labour market outcomes can hide important differences across individuals. For instance, workers performing highly non routine or interactive tasks - that is, tasks that are arguably difficult or more costly to offshore - are less likely to suffer the consequences of increased offshoring intensity. Numerous empirical studies indicate that in terms of objective job loss risk, high-skilled workers tend to be less affected by offshoring than low-skilled worker (Görg and Görlich, 2012, 2015). Moreover, the risk of job loss is higher for blue-collar workers (Lo Turco et al., 2013) and workers performing nonroutine and interactive tasks (Baumgarten, 2015). One of the objectives of this paper is to examine whether such discrepancies hold when we switch from objective job loss risks to perceived risks and job satisfaction. To that purpose, we report estimates for four categories of workers: high and low skill, white and blue-collar workers.

There are several reasons to focus on Germany. First, it is one of the biggest markets within the EU. It is also more open to international trade than most other large developed Economies and registers highest level of exports worldwide (Bachmann and Braun, 2011). Second, as emphasised by Bachmann et al. (2014), the German labour markets is highly regulated with rigid wages, and shocks such as outsourcing might well be absorbed through employment rather than through wages, as confirmed by Görg and Görlich (2012). Third, international outsourcing has grown substantially in Germany over recent years. This makes its industry less exposed to external shocks on demand of final consumption goods and would explained why this country returned quite quickly to the level of employment prior to the Great Recession. In particular, German firms takes the opportunity brought about by the proximity of countries in Central and Eastern Europe, abundant in highly skilled workers but with lower wages (Baumgarten, 2015). The period we analysed is also marked by the increase of the participation in China in the trade of all developed countries, including Germany (Huber and Winkler, 2019). Finally, the integration of Germany into GVC is salient. As pointed by OECD (2018) (p. 4), employment driven by foreign final demand increased between 2005 and 2015 in the majority of OECD countries but "Germany is the country among G20 for which a greater part of employment depends on foreign final demand".

\footnotetext{
2 Lurweg (2010) also studies this issue but focus on the service sector.
} 
The paper shows that offshoring is negatively associated with job satisfaction. This effect differs among categories of workers, with high skill white-collar workers being mostly unaffected by offshoring and low skill blue-collar workers suffering the largest negative effects. Discriminating between manufacturing and services activities, we find that the extent of heterogeneity and the offshoring effect is relatively larger in manufacturing industries. We also find that the effect of offshoring intensity upon job satisfaction is more negative and significant in periods of economic decline. The estimates suggest that offshoring is not significantly related with job insecurity, a result that applies to all workers' categories. Still, increases in offshoring intensity can lead to significantly higher job risks during periods of economic decline.

The paper is organized as follows. Section 2 describes the theoretical background. Section 3 describes the dataset and variables used in the regressions. Section 4 presents the results. Section 5 includes a battery of sensitivity checks and complementary anslises. Section 6 contains the concluding remarks. The paper includes an Appendix that describes the correspondence between NACE industry codes and TiVA industries.

\section{Background}

Theoretical predictions concerning the effects of offshoring on wages and employment are not as clear-cut as international trade theory predicted (Stolper and Samuelson, 1941). The effects of production fragmentation on employment are far from straightforward. The effects on wages have been more intensively studied so far. However, we can draw some lessons in terms of job satisfaction or job insecurities perception, as long as a foreseen decrease in wages could be assimilated with a risk of unemployment.

The seminal reference in this literature is the theoretical model of Grossman and RossiHansberg (2008) that draws the attention to the fact that the fragmentation of production at the international level calls for a new approximation to trade and trade policies where trade does not consist in exchanging goods but exchanging tasks and value added. Thanks to advances in transportation and communications technology, it is increasingly viable to separate tasks in time and space. Certain type of tasks or labour can more easily be performed abroad. According to these authors, the decision to offshore poses a trade-off between the cost advantage of offshoring some tasks against the difficulties to supervise and coordinate the work. This is a reason why offshoring is not beneficial for all the tasks. Then, firms that can relate more intensively on offshorable tasks would expand and increase their demand for local workers who realise less offshorable tasks and whose productivity has increased. ${ }^{3}$ Grossman and RossiHansberg (2006) approximate the offshorable category of works by least skilled blue-collars and conclude that productivity gains and improvement in the terms of trade allow compensating the falling demand for this category of labour, ending up with a moderated reduction of wages. Wright (2014) offers a more detailed empirical verification of the previous model using US

\footnotetext{
3 Grossman and Rossi-Hansberg (2008) complete their model to account for the recent debate about offshoring of high skilled tasks in particular in the service sector. They also conclude that the productivity gains would mitigate the reduction of wages of high skilled at home.
} 
data. They approximate the nature of work by low- and high-skill wages. Their results support the prediction of Grossman and Rossi-Hansberg (2008), especially regarding productivity gains.

Studies exploring the determinants of changes in the nature of work in industrialized countries illustrate that there is a variety of forces at play in the economy, which alters the distribution of workplace tasks. There is a consensus in the literature (Hummels et al., 2018, for a survey) to consider, at least, two important distinct features of offshorable tasks, regardless skill requirements. First, routine tasks can be transmitted in a codified form and more easily transferred from one firm to another, or coordinated from abroad (Autor et al., 2013). Moreover, Blinder (2006) points out that tasks requiring more interaction are less easily offshorable. Ottaviano et al. (2013) underline that offshoring would in turn induce workers to perform more interactive tasks.

\subsection{Offshoring and wages}

Recent studies confirm the importance of the nature of tasks when accounting for the effects of offshoring on wages. Ebenstein et al. (2014) support the hypothesis that wage losses from offshoring are more pronounced for routine tasks. For the US, they show that globalization may affect wages by displacing workers from the manufacturing sector to other sectors in which they obtain less wages. Moreover, the negative wage effect of low-income-country offshoring is especially pronounced for the workers whose occupations have high routine-task indices. Hummels et al. (2014) draw similar conclusions in the Danish case. Conditional on education, workers suffer larger wage declines in response to offshoring if their occupations have high routineness. ${ }^{4}$

The impact of offshoring on wages has been extensively studied in the case of Germany using different methodologies. Baumgarten et al. (2013) and Brändle and Koch (2015) have used the German Qualification and Career Survey to assign a task profile to the occupations listed in the survey they use (GSOEP and BIBB Survey, respectively). The German Qualifications and Career survey is a random sample of around one tenth of the German labour force, which contains detailed information on workplace and workers characteristics, including occupation and industry level variables. ${ }^{5}$ This information allows for the matching between occupations and task profiles Following this strategy, Brändle and Koch (2015) evidence that most manufacturing sectors, and many of the tasks performed in this area are both easily offshorable and outsourceable. Baumgarten et al. (2013) have linked the GSOEP to German Qualification and Career Survey to qualify properly tasks. Their findings support the hypothesis according to which offshoring would have less negative impact on wages of workers which

\footnotetext{
4 Other authors have studied similar questions for other countries, including Casabianca et al. (2019) for Peru; Consoli et al. (2016) for US; Parteka (2018) for Poland and Parteka and Wolszczak-Derlacz (2019) for a set of European countries and the United States.

5 The task profile of German workplaces are classified according to objective and subjective information. Objective information includes the declaration of the main activity of the job and the use of workplace tools, while subjective questions refer to the worker's assessment of the skills required to perform a job and the worker's assessment of the job's requirements such as the degree of repetitiveness, the relevance of deadlines, or the adaptation to new situations.
} 
tasks require a higher degree of interactivity and are non-routine. Becker et al. (2013), using plant data, evidence that high offshoring is associated with large shares of non-routine-task workers and interactive-task workers at the headquarters. Görg and Görlich (2012) conclude that the nexus between export intensities of industries (or imports) and wages are weak, while trade would have more obvious effects on employment. Services offshoring would matter more than material offshoring for wages. Görg and Görlich (2015) re-examine similar questions focusing on the difference among temporary and permanent workers. In this more recent study, they account for offshoring at the industry level using data from the world input-output database (WIOD) where offshoring is measured by the share of imported value added in industry production. They conclude that the effects of offshoring on wages is similar for temporary and permanent. Taking a different perspective, Hogrefe and Yao (2016) compare transitory short-term fluctuations and permanent fluctuations of individuals' income of German workers. They find that the latter would decrease with offshoring, and especially with offshoring to low-income destinations.

\subsection{Job insecurity}

The effect of offshoring on perceived job insecurity has been scarcely studied but we rely in this section on studies that investigate the effect of offshoring on observed turnovers, risk of losing jobs, switch to other sectors or to unemployment. In line with the findings of Grossman and Rossi-Hansberg (2008), offshoring may have contradictory effects on employment, which make rather unclear the overall expected effect and preview an increase in job insecurity. On the one hand, offshoring may induce a substitution of domestic workers by foreign suppliers provoking job losses. On the other hand, domestic firms may gain in market shares by increasing their productivity and thereby raise the demand for local workers.

Crinó (2009) conduct an exhaustive survey of the empirical literature on this matter and concludes that relocation of production activities (material offshoring) seems to raise the volatility of employment, while service offshoring would have a lower impact on total employment but would favour high-skilled white-collar employees. She conjectures that these differences emerge from the still limited extension of service offshoring. Moreover, service offshoring also contributes to create new jobs in the domestic market. Evidence on services offshoring is still scarce to draw robust conclusions. An exception is Liu and Trefler (2019) who find that service offshoring to China and India has larger effects on switching down (switching to an occupation that pays less on average than the current occupation) than on switching up, in the US. Service offshoring would also have not affected so much the average wage of the workers from the service sector but would have raised unemployment rate of these whitecollars.

With a similar setting, Görg and Görlich (2012) rely on objective unemployment hazards to study the different effect of trade exposure (measured using gross trade values) on the probability for workers to lose their jobs. They compare export intensive and non -export intensive sectors, and distinguish between service and material offshoring and between different categories of skilled workers. Their results tend to show that the effects of trade on unemployment probabilities (and on wages) are small, except for services industries where 
export exposure is significantly correlated with high probability of becoming unemployed. Görg and Görlich (2015) underline that offshoring increases the unemployment risk of temporary low-skilled workers more than the one of permanent low-skilled workers. Moreover, offshoring may, through reallocation of activities lead to more employment opportunities for high-skilled workers.

Bachmann and Braun (2011) use the IAB Employment Sample to explore the effect of trade on individual risk of losing a job in Germany. Both conclude that outsourcing would contribute to job stability in the service sector. The authors conclude that outsourcing has a positive but small impact on overall job stability in the manufacturing sector but would hurt more mediumskilled and older workers. Baumgarten (2015) with the same dataset focuses on the difference between material and service offshoring. They confirm a small impact of both type of offshoring on job security, even if the risk is higher for workers performing non-routine and interactive tasks.

Following similar strategies, other authors have focused on other countries. Pfaffermayr et al. (2007) find that outsourcing increases the labour turnover in Austria. For Italy, Lo Turco et al. (2013) conclude that material offshoring to low income countries would hurt especially blue collars by raising their probability to exit the manufacturing sectors. White collars would be more affected by offshoring to high-income countries that would increase the likelihood of switching to another job within the manufacturing sector.

Only a few studies have investigated the nexus between trade and a subjective measure of job insecurity as we do. Lurweg (2010) focuses on the job insecurity of workers in German service industries using both a "subjective" and a more "objective" measure. Employees from sectors producing a traded service, or a service which exports are growing, are objectively more exposed to unemployment, and their feelings accurately reflect the situation. Thus, this study does not account for manufacturing industries, the ones that are more affected by offshoring. Geishecker et al (2012) use data from Germany covering the 1995-2006 period to examine the relation between offshoring and job loss fears. Using linear fixed effects estimates, they find that offshoring to low-wage countries significantly raises job loss fears whilst offshoring to high-wage countries somewhat lowers them. Moreover, their results indicate that high-skilled workers are more sensitive to offshoring. Finally, Savsin and Akay (2020) study the impact of offshoring on mental well-being of German, British and Australian workers over the period 2000 to 2013. They find that offshoring negatively affects workers' mental well-being more than objective and subjective job security do, and the effect is larger in business services and among high-skilled workers. 


\section{$3 \quad$ Empirical strategy}

\subsection{Data set and variables}

The analysis is based on individual level data from the 2000-2013 waves of the German Social Economic Panel (SOEP). Initiated in 1984, the German GSOEP is a representative longitudinal annual household survey that contains information on a large set of personal and household characteristics. ${ }^{6}$ It also includes the industry in which an individual works. The sample includes full-time employees of prime age (i.e., aged 18-64) who are employed in manufacturing (NACE 15-36) or services industries (NACE 40-74). We remove the self-employed and those currently employed in (occupational) education or retraining. The various reduction steps result in an unbalanced panel of 69,733 observations from 17,888 respondents.

Job satisfaction is measured with a question in which respondents are asked "How satisfied are you with your job (if employed)?" on a 0 to 10 scale, where 0 is "completely dissatisfied" and 10 is "completely satisfied". Hereafter, the answer to this will be referred to as Job Satisfaction (JS). Despite a long tradition among sociologists and psychologists, subjective data was subject to criticisms among some economists concerned about the potential biases arising from cultural differences, framing problems, cognitive bias, and mood effects. Although for reasons of space we do not enter into details, we note that the evidence accumulated over recent years has proven the validity and consistency of self-reported data. In a nutshell, self-reported measures of job satisfaction have shown predictive power over relevant actions such as job absence, dismissals, job quits and productivity.

Perceived Job Insecurity (JI) is captured by "How concerned are you about the following issues: Your job security (if you are employed)?” Respondents can either answer "very concerned", "somewhat concerned", or "not concerned at all". We consider respondents to perceive their job as insecure if they check "very concerned" or "somewhat concerned", whereas respondents perceive their jobs as secure if they responded "not at all concerned". Therefore, our measure of job insecurity is a binary variable.

As for the measurement of offshoring, there is consensus that exports and imports have become a poor indicator of openness. Due to the increasing importance of international trade of intermediate products, gross values of exports does not reflect accurately the domestic value added embodied in goods and services while imports may include not only foreign value added but also domestic value added incorporated in previous stage of the production of these imported goods. To avoid the double account of foreign value added embodied in exports and in imports, it is necessary disentangle the content of domestic and foreign value added in gross exports and, additionally to take into account the domestic content incorporated in imported inputs used in exported production.

Several methodological proposals have emerged in recent years, including Koopman et al. (2010, 2014), Daudin et al. (2011), Johnson and Noguera (2012), Timmer (2012) and Timmer et

6 Every year, there are nearly 11,000 households and more than 20,000 persons sampled. The data provide information on all household members, consisting of Germans living in the Old and New German States, foreigners, and recent immigrants to Germany. For detailed information see Wagner at al. (2007). In this paper we use the GSOEP files corresponding to the soep.v30 version, and rely on the yearly \$PEQUIV, \$PGEN and \$HGEN files of the data set. 
al. (2014). With some nuances, all the calculations proposed are based on tables input-output at the world level that provide intensity in the use of intermediate goods by sectors and partner countries. They end up with the Foreign Value Added (FVA) in country gross exports and the Domestic Value Added (DVA) in imports. FVA and DVA can be expressed either in function of total gross exports or imports or in terms of industry production, depending on the purpose of the study. There are two main sources providing such data for large sample of countries: world input-output database (WIOD) from the World Bank and the Trade in Value Added (TiVA) database from the OCDE. The period covered by the second one is longer and offers the advantage of directly provide the main indicators already calculated. To proxy the intensity of offshoring, we use in a first step, the indicator Foreign Value Added in country gross exports (FVAX) expressed as a share of total gross exports (EXP) from the 2016 version of TiVA (2000-2011) and extrapolate using the 2018 version of TiVA for the years 2012-2013. A higher value of the indicator expresses a higher intensity of offshoring.

TiVA data are provided at a quite broad aggregated level. The categories are shown in the Appendix. These include several sectors of the two-digit ISIC rev 4 nomenclature. We match this classification with the 2-digit NACE industry codes included in the GSOEP and, therefore, pair individual information in the GSOEP sample with industry offshoring levels. As a limitation, TiVA categories are more aggregated than NACE codes. Hence, some industries from the GSOEP classification have been assigned the same offshoring intensity. For almost all industries the matching between TiVA and NACE is univocal except for 2 categories, which belong to several TiVA sectors. In these cases, we aggregate the FVAX of these TiVA industries, and we calculate the share in overall exports of this broad category. Overall, the 59 NACE industries of the GSOEP have been assigned 36 offshoring intensities (see appendix). Specifically, the 23 manufactures' industries that have been matched with 18 TiVA categories, the 28 services' industries has been matched with 17 TiVA industries and, finally, the 8 industries of the primary sector (NACE 1 to 14) correspond to 4 TiVA categories. In the Appendix we include a table with the correspondence between TiVA and NACE industries.

To test how offshoring affects job satisfaction and job security of workers performing different tasks, we group the 2-digit level codes from the International Standard Classification of Occupations (ISCO) provided in the GSOEP into four different task categories following Grossman and Rossi-Hansberg (2006) among others. This classification could be improved in the future following the approach of Baumgarten et al. (2013). Therefore, we differentiate among four task categories: i) high skilled white collar; ii) low skilled white collar; iii) high skilled blue collar and iv) low skilled blue collar. ${ }^{7}$ We hypothesise low skilled blue collars to realise more routine and offshorable and as a consequence to be more affected by offshoring.

\footnotetext{
7 Each category corresponds to specific ISCO 88 occupation codes: i) high skilled white collar (legislators, senior officials and managers, professionals and technicians and associate professionals); ii) low skilled white collar (clerks and service workers and shop and market sales workers); iii) high skilled blue collar (skilled agricultural and fishery workers and craft and related trades workers) and iv) low skilled blue collar (plant and machine operators and assemblers and elementary occupations). Armed forces are excluded.
} 


\subsection{Specification and research hypotheses}

Job satisfaction is assumed to be a function of individual and job characteristics,

$$
J S_{i t}=f\left(Y^{*}\left(X_{i t}, O_{i t-1}, \varepsilon_{i t}\right)\right)
$$

where $J S_{i t}$ denotes job satisfaction of individual $i$ at time $t$. Vector $X$ includes monthly labour income in gross terms, i.e., before taxes and social security contributions are deducted and, to account for inflation, transformed into real terms buy using the yearly consumer price included in the GSOEP. X also included age and age squared, job tenure, hours of work years of schooling and number of children and adults at home. All the variables are in logs. The model also includes health status, marital status, a full vector of industry dummy variables, controls for the type of task performed by the individual, dummies for the 16 German federal states and year fixed effects. $O_{i t-1}$ is the offshoring intensity of the industry in which individual $i$ worked in $t$ 1 , and $\varepsilon_{i t}$ is an independent error term. We proceed likewise to define the equation for job insecurity,

$$
J I_{i t}=f\left(Y^{*}\left(X_{i t}, O_{i t-1}, \varepsilon_{i t}\right)\right)
$$

We must note that we use offshoring intensity at time $t-1$ to explain job satisfaction and job insecurity at time $t$. Since the offshoring variable pre-dates the dependent variable, we are factoring out from the estimates any spurious correlation that may run from contemporaneous job satisfaction and insecurity to offshoring intensity. Another potential concern with the direction of causality is the possibility that offshoring is correlated with industry-specific nonobservables. Lower JS in industries with more offshoring intensity may suggest a true effect but, also, that these industries have other characteristics that affect negatively JS. This could be the case if, for example, workers in industries exposed to more import competition have worse working conditions (less hours flexibility, higher turnovers, etc). A same reasoning applies to JI. We address this concern by, firstly, including the full vector of industry dummies, so that any characteristic of the industry that may affect both offshoring and job satisfaction and/or job insecurity are controlled for in our estimations. In addition, we allow for full sets of industryyear fixed effects, which flexibly absorb any other time-varying determinant of job satisfaction and job insecurity operating at the sector level.

As a second concern, working in specific industries could reflect individual unobserved characteristics: for example, individuals who self-select in "Arts, entertainment, recreation and other service activities" may have specific personality traits that are correlated with the perception of their jobs and the satisfaction derived from them. Therefore, we estimate the equations allowing for individual fixed effects. Fixed effects remove time-invariant determinants of job satisfaction and job insecurity at the individual level (e.g., differences in personality, attitudes towards risk, etc) and imply that we exploit within-person variation over time for model identification.

We take reported JS to be cardinal. This is, we assume that the distance between the eleven satisfaction categories carry a meaning. It has been shown that assuming cardinality as oppose to regress satisfaction with ordinal models is rather irrelevant for the results in terms of tradeoffs between explanatory variables (Ferrer-i-Carbonell and Frijters, 2004), while it has the advantage of yielding coefficients that can be directly interpreted as marginal effects. In the JS 
equation we rely on the Probit Adapted Ordinary Least Squares (POLS) as developed by Van Praag and Ferrer-i-Carbonell (2008, p. 29-34). As a robustness check, we have estimated the model with the standard linear model and found very small differences in terms of trade-offs between variables and statistical significance.

Implementing POLS begins by deriving $\left\{\mu_{\mathrm{j}}\right\}_{\mathrm{j}=0}^{\mathrm{J}}$ values of a standard normal associated with the cumulative frequencies of the $J$ different categories of the dependent variable, with $\mu_{0}=$ $-\infty, \mu_{\mathrm{J}}=\infty$. Then the expectation of a standard normally distributed variable is taken for an interval between any two adjacent values. Thus, if the true unobserved continuous variable for individual $i$ at time $t$ is $J S_{i t}^{*}$, where the observed is $J S_{i t}=\mathrm{j}$ if $\mu_{\mathrm{j}-1}<J S_{i t}^{*} \leq \mu_{\mathrm{j}}, \mathrm{j}=1, \ldots, \mathrm{J}$, then the conditional expectation of the latent variable is given by:

$$
\ddot{S}_{i t}=\mathrm{E}\left(J S_{i t}^{*} \mid \mu_{\mathrm{j}-1}<J S_{i t}^{*}<\mu_{\mathrm{j}}\right)=\frac{\mathrm{n}\left(\mu_{\mathrm{j}-1}\right)-\mathrm{n}\left(\mu_{\mathrm{j}}\right)}{\mathrm{N}\left(\mu_{\mathrm{j}}\right)-\mathrm{N}\left(\mu_{\mathrm{j}-1}\right)}
$$

where $n$ is the normal density and $N$ is the cumulative normal distribution. $\ddot{J} \ddot{S}_{i t}$ is normalized so that it has a zero mean and a standard deviation of one. The approach allows the application of a linear estimator on the conditional expectations:

$$
\ddot{J S}_{\mathrm{it}}=\alpha \mathrm{X}_{\mathrm{it}}+\beta \mathrm{O}_{\mathrm{it}-1}+\mathrm{v}_{\mathrm{i}}+\eta_{\mathrm{it}}
$$

where $\eta_{i t} \eta_{i t}$ an independent error term for individual $i$ at time $t$ and $v_{i}$ is an individual effect that varies across individuals and is constant over time. We hypothesize that the effect that offshoring intensity has on $J S$ depends on the type of task performed by the individual. Thus we define a dummy variable $T_{i t}^{j}$ that takes value 1 if the individual's task corresponds to category $j$, $j=1,2,3,4$, and include an interaction term between $O$ and the corresponding task category. We leave $j=1$ (high skilled white collar worker) as the reference category and therefore do not include the interaction term in this case,

$$
\ddot{J}_{i t}=\alpha X_{i t}+\beta O_{i t-1}+\gamma T_{i t}^{j} \times O_{i t-1}+v_{i}+\eta_{i t}
$$

A well-determined coefficient on the type of task-offshoring interaction term $\gamma$ would imply that the effects of offshoring differ between individuals performing different tasks.

As for our binary dependent variable, job insecurity, it may be modelled as a function of a latent variable $J I^{*}$ that is not measured, is continuous, has a threshold point that determines the observed value of JI, and is a function of observable characteristics

$$
\mathrm{JI}_{\mathrm{it}}^{*}=\alpha \mathrm{X}_{\mathrm{it}}+\beta \mathrm{O}_{\mathrm{it}-1}+\gamma \mathrm{T}_{\mathrm{it}}^{\mathrm{j}} \times \mathrm{O}_{\mathrm{it}-1}+\mathrm{v}_{\mathrm{i}}+\eta_{\mathrm{it}}
$$

with

$$
\begin{array}{lll}
J I_{i t}=1 & \text { if } & J I_{i t}^{*}>0 \\
\mathrm{JI}_{\mathrm{it}}=0 & \text { if } & \mathrm{JI}_{\mathrm{it}}^{*} \leq 0
\end{array}
$$

For simplicity, we will ignore the binary dependent nature of the dependent variable and replace $J I_{i t}^{*}$ with $J I_{i t}$ in Eq. (6). The advantage of using the linear estimator is that the coefficients can be directly interpreted as marginal effects and these are very similar to those 
obtained using non-linear methods. The results from a probit model are available from the authors upon request.

\section{$4 \quad$ Results}

\subsection{Descriptive analysis}

In Table 1, we report summary statistics. Average JS is 7.0 whereas $14.5 \%$ of the workers report to be insecure at their jobs. These figures indicate that, in general, individuals are fairly satisfied and feel secure about conserving their jobs. Average gross labour income amounts to $€ 2,540.7$ and $11.9 \%$ of the sample has a temporary contract. Foreign value added represents on average $22.4 \%$ of gross exports with a sizable dispersion among industries, ranging from a minimum of $2.6 \%$ ("Real state, property activities") to a maximum of $46.0 \%$ ("Manufacturing of basic

Table 1. Summary statistics

\begin{tabular}{lrrrr}
\hline \hline & Average & \multicolumn{1}{c}{ std } & Min & Max \\
\cline { 2 - 5 } Job satisfaction & 7.012 & 1.990 & 0 & 10 \\
Job insecurity & 0.145 & 0.352 & 0 & 1 \\
Income & 2540.730 & 1810.264 & 0 & 40000 \\
Offshoring & 14.374 & 7.897 & 2.6 & 46.03 \\
High skilled white collar & 0.484 & 0.500 & 0 & 1 \\
Low skilled white collar & 0.227 & 0.419 & 0 & 1 \\
High skilled blue collar & 0.153 & 0.360 & 0 & 1 \\
Low skilled blue collar & 0.136 & 0.343 & 0 & 1 \\
Temporary contract & 0.119 & 0.323 & 0 & 1 \\
Woman & 0.477 & 0.489 & 0 & 1 \\
Age & 42.154 & 11.183 & 18 & 65 \\
Tenure & 11.515 & 10.129 & 0 & 52 \\
Working hours & 39.410 & 10.910 & 10 & 99 \\
Years of schooling & 12.343 & 2.579 & 7 & 18 \\
Numer of adults & 2.261 & 0.866 & 1 & 10 \\
Number of children & 0.625 & 0.914 & 0 & 9 \\
Married & 0.644 & 0.479 & 0 & 1 \\
Single & 0.260 & 0.438 & 0 & 1 \\
Divorced & 0.083 & 0.276 & 0 & 1 \\
Widowed & 0.014 & 0.115 & 0 & 1 \\
Badhealth & 0.102 & 0.303 & 0 & 1 \\
\hline \hline
\end{tabular}

Note: Source: GSOEP 2000-2013 waves 
metals”). Women account for $47.7 \%$ of the sample. Average age and tenure amount to 42.2 and 11.5 years, respectively. On average, individuals in the sample work 39.4 hours per week,have completed 12.6 years of schooling, live in a household with 2.3 adults and 0.6 children. Most individuals in the sample are married (64.4\%) and 10\% report a bad health status.

\subsection{Offshoring and job satisfaction}

In Table 2, we report the estimates of the determinants of JS. All the effects reported in Table 2 are expressed as standard deviations of JS. Model 1a constitutes a parsimonious specification, controlling only for individual and year fixed effects. Before focusing on the effects of offshoring, we first describe the results for the remaining covariates. The results do not present surprises for the connoisseur of the literature. Job satisfaction depends positively on labour income and negatively on age, tenure and hours of work. Years of schooling are negatively related to JS, a result that can be explained by the negative effects that overeducation exerts upon satisfaction at the job, a phenomenon that is more prevalent among the educated. We do not detect significant differences due to contract duration. Moreover, singles and individuals living in households with more adults report lower JS, while having a bad health status emerges as a salient determinant of job dissatisfaction.

Turning to the crux of our analysis, we find that offshoring intensity is negatively related with JS. The coefficient is significant at the $5 \%$ level and suggests that a 0.01 increase in logarithmic offshoring intensity (an approximately $1 \%$ increase of the index) is associated with a loss of 0.00033 standard deviations of JS. The figure may seem negligible but it should not be so if we compare it with the relative effects of other covariates. Satisfaction equations can be used to assess the importance of a given dimension relative to other dimensions, and to construct equivalence scales between relevant variables (Ferrer-i-Carbonell, 2013). For instance, we may take labour income as a reference, since it is one of the most relevant determinants of JS. An 0.01 increase in logarithmic labour income (an approximately $1 \%$ increase in labour income) is associated with an increase of 0.00131 standard deviations of JS. Therefore, using the coefficient of labour income as a reference we can calculate the trade-off between labour income and offshoring that maintains JS constant. The reference individual would need a compensation of about $0.252 \%$ of her labour income to experience a $1 \%$ increase in offshoring intensity $([\exp (0.033 / 0.131 \times 0.01)-1] \times 100=0.252)$. Similarly, other things equal, a $1 \%$ increase in offshoring intensity would be equivalent to an increase in hours worked of $1.80 \%$ $([\exp (0.033 / 0.056 \times 0.01)-1] \times 100=1.8)$.

In Model 1b we include a full vector of industry dummies and industry-year fixed effects. In this case, the estimate of the offshoring fails to be statistically significant. This result suggests the existence of industry characteristics that may affect both offshoring and job satisfaction. There might be time-varying determinants of offshoring and job satisfaction operating at the sector level. 
Table 2. Job Satisfaction and offshoring

\begin{tabular}{|c|c|c|c|c|c|c|c|c|}
\hline & \multicolumn{2}{|c|}{ Model 1a } & \multicolumn{2}{|c|}{ Model 1b } & \multicolumn{2}{|c|}{ Model 2a } & \multicolumn{2}{|c|}{ Model 2b } \\
\hline & coefficient & $\mathrm{t}$ & coefficient & $\mathrm{t}$ & coefficient & $\mathrm{t}$ & coefficient & $\mathrm{t}$ \\
\hline Ln(Income) & $0.131^{* * *}$ & 9.72 & $0.133^{* * *}$ & 9.82 & $0.129^{* * *}$ & 9.58 & $0.131^{* * *}$ & 9.68 \\
\hline Offshoring & $-0.033^{* *}$ & -2.38 & -0.036 & 122 & -0.011 & -0.77 & -0.018 & -0.61 \\
\hline \multicolumn{3}{|c|}{ Offshoring $\times$ low skilled white collar } & & & $-0.024^{* * *}$ & -3.56 & $-0.021^{* * *}$ & -3.19 \\
\hline \multicolumn{3}{|c|}{ Offshoring $\times$ high skilled blue collar } & & & $-0.032^{* * *}$ & -3.75 & $-0.036^{* * *}$ & -4.13 \\
\hline \multicolumn{3}{|c|}{ Offshoring $\times$ low skilled blue collar } & & & $-0.040^{* * *}$ & -4.57 & $-0.042^{* * *}$ & -4.79 \\
\hline Temporary & 0.001 & 0.05 & -0.006 & -0.38 & 0.001 & 0.04 & -0.006 & -0.39 \\
\hline Ln(age) & $-5.474^{* * *}$ & -2.98 & $-5.531^{* * *}$ & -3.01 & $-5.315^{* * *}$ & -2.89 & $-5.383^{* * *}$ & -2.93 \\
\hline $\operatorname{Ln}(\text { age })^{2}$ & $0.977^{* * *}$ & 2.78 & $0.985^{* * *}$ & 2.82 & $0.946^{* * *}$ & 2.69 & $0.955^{* * *}$ & 2.72 \\
\hline Ln(tenure) & $-0.157^{* * *}$ & -24.9 & $-0.155^{* * *}$ & -24.6 & $-0.157^{* * *}$ & -24.9 & $-0.155^{* * *}$ & -24.6 \\
\hline Ln(working hours) & $-0.056^{* * *}$ & -2.62 & $-0.056^{* * *}$ & -2.63 & $-0.057^{* * *}$ & -2.69 & $-0.057^{* * *}$ & -2.71 \\
\hline Ln(years of schooling) & $-0.626^{* * *}$ & -4.41 & $-0.658^{* * *}$ & -4.62 & $-0.653^{* * *}$ & -4.58 & $-0.685^{* * *}$ & -4.81 \\
\hline Ln(adults) & 0.003 & 0.12 & 0.003 & 0.12 & 0.003 & 0.14 & 0.003 & 0.14 \\
\hline Ln(children) & 0.032 & 2.32 & $0.032^{* *}$ & 2.31 & $0.031^{* *}$ & 2.25 & $0.031^{* *}$ & 2.23 \\
\hline Single & $-0.044^{* *}$ & -2.01 & $-0.044^{* *}$ & -2.01 & $-0.044^{* *}$ & -1.98 & $-0.044^{* *}$ & -1.97 \\
\hline Divorced & $-0.072^{* * *}$ & -3.02 & $-0.071^{* * *}$ & -2.98 & $-0.071^{* * *}$ & -3.01 & $-0.070^{* * *}$ & -2.97 \\
\hline Widowed & -0.017 & -0.27 & -0.021 & -0.33 & -0.015 & -0.23 & -0.018 & -0.31 \\
\hline Bad health & $-0.298^{* * *}$ & -22.3 & $-0.298^{* * *}$ & -22.2 & $-0.298^{* * *}$ & -22.2 & $-0.297^{* * *}$ & -22.2 \\
\hline Fixed effect industry & no & & yes & & no & & yes & \\
\hline Fixed effect year & yes & & yes & & yes & & yes & \\
\hline Fixed effect state & yes & & yes & & yes & & yes & \\
\hline $\mathrm{R}^{2}$ - within & 0.040 & & 0.041 & & 0.041 & & 0.042 & \\
\hline No. of obs & 69,733 & & 69,733 & & 69,733 & & 69,733 & \\
\hline
\end{tabular}

Notes: i) Source: GSOEP 2000-2013 waves; ii) ${ }^{* * *}$ denotes significant at the $1 \%$ level, ${ }^{* *}$ denotes significant at the $5 \%$ level; * denotes significant at the $10 \%$ level; iii) The reference individual has a permanent contract, is married, is a high skill white collar worker, has a good health status, average income, age, tenure, hours of work, years of schooling, number of adults and children at home and is exposed to average offshoring levels.

However, once we allow for interactions between offshoring and worker's category we obtain, again, significant effects of offshoring even after controlling for industry (Models 2a and 2b). The models unveil substantial heterogeneity surrounding the offshoring effect. Specifically, we find that the reference individual (a high skilled white-collar worker) is not affected by offshoring intensity. In contrast, workers in the remaining three categories are worse off if they work in industries with higher offshoring intensity. The estimates in Model 2b indicate that a $1 \%$ increase of offshoring intensity would need a compensation of $0.160 \%, 0.275 \%$ and $0.321 \%$ of labour income depending on whether the individuals is a low skilled white collar, high skilled blue collar or low skilled blue collar worker, respectively. Overall, these results tend to show that the estimates obtained in Models 1a and 1b regarding the offshoring effect represent an average across workers from different categories. Once we allow for a differentiated effect, the model is indicative of sensitive differences across groups of workers. The fact that low skilled workers are more sensitive to variations in offshoring would be consistent with the notion that trade accelerates skill biased technological changes through a diffusion of technologies worldwide. 


\subsection{Offshoring and job insecurity}

In Table 3, we focus on the determinants of JI. According to the results, JI depends crucially on contract duration, with workers having temporary contract being more than 12 percentage points more likely to feel insecure at their jobs. JI also depends positively on tenure and bad health. A perhaps surprising result is that workers with more education are more likely to report insecurity. However, we must recall that the results are controlling for individual fixed effects and, therefore, they are based on within individual variation of schooling, a variable that shows very little yearly variation among adult workers. Only $2.5 \%$ of the sample workers register an interannual variation in years of schooling, and most of them (43\%) are aged below 35. It is likely that a small group of young workers with low professional experience and tenure who have recently accessed the labour market drives the positive effect of schooling on JI.

The offshoring coefficient is significant in Model 1a, suggesting that JI rises with offshoring intensity, but turns to non-significant once we add the industry controls in Model 1b. This result suggests that offshoring tends to be higher in industries with higher job insecurity. ${ }^{8}$ There are

Table 3. Job insecurity and offshoring

\begin{tabular}{|c|c|c|c|c|c|c|c|c|}
\hline & \multicolumn{2}{|l|}{ Model 1a } & \multicolumn{2}{|c|}{ Model 1b } & \multicolumn{2}{|c|}{ Model 2a } & \multicolumn{2}{|c|}{ Model 2b } \\
\hline & coefficient & $\mathrm{t}$ & coefficient & $\mathrm{t}$ & coefficient & $\mathrm{t}$ & coefficient & $\mathrm{t}$ \\
\hline Ln(Income) & 0.005 & 0.00 & 0.004 & 0.86 & 0.005 & 0.95 & 0.004 & 0.84 \\
\hline Offshoring & $0.015^{* * *}$ & 2.79 & -0.002 & -0.19 & $0.014^{* * *}$ & 2.65 & -0.002 & -0.16 \\
\hline \multicolumn{3}{|c|}{ Offshoring $\times$ low skilled white collar } & & & -0.001 & -0.56 & -0.002 & -0.61 \\
\hline \multicolumn{3}{|c|}{ Offshoring $\times$ high skilled blue collar } & & & 0.001 & 0.26 & 0.001 & 0.31 \\
\hline \multicolumn{3}{|c|}{ Offshoring $\times$ low skilled blue collar } & & & 0.000 & 0.08 & 0.000 & 0.01 \\
\hline Temporary & $0.122^{* * *}$ & 21.02 & $0.123^{* *}$ & 21.06 & $0.122^{* * *}$ & 21.01 & $0.123^{* * *}$ & 21.1 \\
\hline Ln(age) & 0.364 & 0.53 & 0.346 & 0.51 & 0.371 & 0.54 & 0.355 & 0.52 \\
\hline $\operatorname{Ln}(\text { age })^{2}$ & -0.058 & -0.44 & -0.055 & -0.42 & -0.059 & -0.45 & -0.056 & -0.43 \\
\hline Ln(tenure) & $0.017^{* * *}$ & 7.31 & $0.017^{* *}$ & 7.31 & $0.017^{* * *}$ & 7.28 & $0.017^{* * *}$ & 7.28 \\
\hline Ln(working hours) & 0.005 & 0.67 & 0.006 & 0.75 & 0.005 & 0.66 & 0.006 & 0.73 \\
\hline Ln(years of schooling) & $0.222^{* * *}$ & 4.11 & $0.225^{* *}$ & 4.16 & $0.221^{* * *}$ & 4.11 & $0.224^{* * *}$ & 4.15 \\
\hline Ln(adults) & $0.015^{*}$ & 1.74 & $0.015^{*}$ & 1.76 & $0.015^{*}$ & 1.74 & $0.015^{*}$ & 1.76 \\
\hline Ln(children) & $-0.009^{*}$ & -1.72 & $-0.009^{*}$ & -1.67 & $-0.009^{*}$ & -1.72 & $-0.009^{*}$ & -1.67 \\
\hline Single & -0.008 & -0.92 & -0.008 & -0.96 & -0.008 & -0.92 & -0.008 & -0.96 \\
\hline Divorced & 0.006 & 0.65 & 0.005 & 0.61 & 0.006 & 0.65 & 0.005 & 0.61 \\
\hline Widowed & $-0.039^{*}$ & -1.66 & $-0.039^{*}$ & -1.65 & $-0.039^{*}$ & -1.67 & $-0.039^{*}$ & -1.66 \\
\hline Bad health & $0.028^{* * *}$ & 5.51 & $0.028^{* *}$ & 5.51 & $0.028^{* * *}$ & 5.51 & $0.028^{* * *}$ & 5.51 \\
\hline Fixed effect industry & no & & yes & & no & & yes & \\
\hline Fixed effect year & yes & & yes & & yes & & yes & \\
\hline Fixed effect state & yes & & yes & & yes & & yes & \\
\hline $\mathrm{R}^{2}$ - within & 0.025 & & 0.026 & & 0.025 & & 0.026 & \\
\hline No. of obs & 69,733 & & 69,733 & & 69,733 & & 69,733 & \\
\hline
\end{tabular}

Notes: i) Source: GSOEP 2000-2013 waves; ii) ${ }^{* * *}$ denotes significant at the $1 \%$ level, ${ }^{* *}$ denotes significant at the $5 \%$ level; * denotes significant at the $10 \%$ level; iii) The reference individual has a permanent contract, is married, is a high skill white collar worker, has a good health status, average income, age, tenure, hours of work, years of schooling, number of adults and children at home and is exposed to average offshoring levels.

8 This is confirmed by the raw data. When going from the bottom $25 \%$ to the top $25 \%$ of the offshoring intensity distribution, the proportion of insecure workers goes from $11.3 \%$ to $16.8 \%$. 
several explanations that may account for the non-significant relation between JI and offshoring. Firstly, it may be the case that adjustments following macroeconomic and offshoring shocks lead to fewer hirings but not to job separations, especially in a country with strict dismissal protection regulations like Germany. For instance, using German data Baumgarten (2015) finds that offshoring is not, on average, associated with significantly higher transition rates from employment to non-employment. Also based on German data and objective employment transitions, Bachmann and Braun (2011) find only a modest relationship between offshoring and employment transitions, although in their case the coefficient is statistically significant in some specifications. Using subjective appraisals of job insecurity and GSOEP data, Savsin and Akay (2020) find that offshoring is not statistically significant on perceptions of job security. Moreover, they test the robustness of their result by controlling for potential confounding macroeconomic factors related to technological development, labour market wages, employment and productivity. The underlying assumption is that these "globalization" measures might confound the relationship between offshoring, well-being and job insecurity if they correlate with offshoring within each industry. However, they find that the magnitude and significance of the baseline model is hardly affected by inclusion of these variables, thus supporting the notion that well-being and JI are depend importantly on the industry's idiosyncratic factors.

Secondly, workers performing offshorable tasks may suffer from wage cuts instead of job separations. If most of the adjustment occurs though wages, workers may not perceive increased offshoring as a signal of increased job risk. ${ }^{9}$ Thirdly, there might be industry characteristics that are simultaneously correlated with offshoring and JI. The industry dummies included in the specifications can potentially soak up the effect of the offshoring variable if changes in offshoring intensity are correlated with industry-level factors that have a direct impact on perceived JI, such as average turnover and dismissal rates, union density and hiring conditions.

In Models 2a and 2b, we allow for a differential effect of offshoring across categories of workers. The interaction terms fail to be statistically significant, thus suggesting that as far as JI is concerned, offshoring intensity at the industry level would affect in the same manner all the categories of workers (high skilled white collar, low skilled white collar, high skilled blue collar and low skilled blue collar). However, since on average offshoring has no significant effect on JI, we consider that JI is more related with characteristics of the industries. For instance, Geishecker (2008) reports that the effect of offshoring on employment transitions depends on the duration of the employment spell but not on the worker skill group. Moreover, the results in Görg and Görlich (2015) suggest that the link between offshoring and unemployment may differ and even revert sign across industries. For instance, they find that services offshoring to may lead to productivity improvements which imply higher job security, while materials offshoring is largely innocuous in terms of job risk. Therefore, to the extent that the various skills groups of workers are distributed among all industries, estimates that average across industries may fail to be statistically significant.

\footnotetext{
9 To shed light on this issue, we estimated a set of wage regressions including the same explanatory variables as in the benchmark model, the underlying hypothesis being that offshoring intensity negatively affects wages. We found a negative relationship, with the wage effects of a $1 \%$ increase in offshoring intensity ranging from $-0.28 \%$ to $-0.34 \%$. However, in all cases the coefficient failed to be significant at conventional levels.
} 


\section{$5 \quad$ Discussion and sensitivity checks}

The results show that the effects of offshoring on JS differ across workers from different categories. High skill white-collar workers are mostly unaffected by offshoring, while the remaining categories are significantly worse off, the higher the offshoring intensity in their industry is. On the opposite, JI is not affected by the offshoring intensity, a result that holds among all workers' categories.

In this section, we test the robustness of these results. To that purpose, we perform a set of sensitivity checks. First, we start by noting that the results presented so far include sectors that are intensive in natural resources. This is the case of agriculture, hunting, forestry, mining and extraction (NACE codes from 1 to 14). Although only 1.05\% of the sample workers are employed in these sectors, it might be the case that the inclusion of these activities distorts to some extent the relation between offshoring, JS and JI. This is so because imports in sectors that are intensive in natural resources may not reflect the displacement or substitution of national production by international competitors, but mirrors the fact that the country does not possess the natural resources required in the production process. If this is the case, the offshoring index used in the regressions would not capture intentional import competition but a mere need of intermediate inputs. Then, these sectors intensive in natural resources are mainly traded on an inter-industry basis with no possibility of offshoring. In Table 4, we re-estimate the Models 2a and $2 \mathrm{~b}$ after dropping individuals employed in natural resources intensive methods. For space reasons, we report only the income and offshoring coefficients. Again, we find that the offshoring effect on JS differs among workers with different categories, the more negative effect corresponding to low skilled blue-collar workers. We find that the estimates remain practically unaltered relative to the previous estimates. The same applies to the JI equations. Offshoring intensity affects positively the probability of feeling insecure at the job (Model 2a). However, this effect is mostly driven by non-observable conditioners at the industry level. Once we introduce controls for activity sector (Model 2b), the coefficient becomes non-significant. Second, we calculate separate regressions for workers employed in the manufacturing (NACE 15-36) and services (NACE 40-74) activities. Indeed, manufacturing includes activities more prone to the fragmentation of production since products include a large variety of parts and components. In contrast, services include many non-tradable activities even if offshoring of some services has been facilitated by ICT in recent years. The results, reported in Tables 5 and 6 , show that offshoring intensity is negatively related with JS, both in manufacturing and services industries. Within each sector we detect, in line with the general result, substantial heterogeneity of workers' sensitivity to offshoring, with those in inferior task categories being more affected by offshoring. Still, the negative effect of offshoring upon JS is higher in manufacturing than in service activities once we control for industry fixed-effects. In this case (Model 2b) the level effect of offshoring or, in other words, the effect of offshoring for the reference individual (a high skilled white-collar worker) is negative, high and significant, suggesting that all workers in manufacturing activities are affected by offshoring regardless of their task category. In terms of JI, the results confirm previous findings and no remarkable differences emerge. Once we include the industry dummies and industry-year fixed effects, the estimates of the offshoring effect fail to be statistically significant and we detect no difference between tasks. 
Economics: The Open-Access, Open-Assessment E-Journal 14 (2020-23)

Table 4. Job satisfaction, job insecurity and offshoring - Excluding NACE 1-14 industries

\begin{tabular}{|c|c|c|c|c|c|c|c|c|}
\hline & \multicolumn{4}{|c|}{ Job satisfaction } & \multicolumn{4}{|c|}{ Job insecurity } \\
\hline & \multicolumn{2}{|c|}{ Model 2a } & \multicolumn{2}{|l|}{ Model 2b } & \multicolumn{2}{|c|}{ Model 2a } & \multicolumn{2}{|c|}{ Model 2b } \\
\hline & coefficient & $\mathrm{t}$ & coefficient & $\mathrm{t}$ & coefficient & $\mathrm{t}$ & coefficient & $\mathrm{t}$ \\
\hline Ln(Income) & $0.127^{* * *}$ & 9.36 & $0.127^{* * *}$ & 9.35 & 0.004 & 0.77 & 0.004 & 0.72 \\
\hline Offshoring & -0.021 & -1.43 & -0.030 & -1.00 & $0.017^{* * *}$ & 3.00 & 0.000 & 0.02 \\
\hline Offshoring $\times$ low skilled white collar & $-0.025^{* * *}$ & -3.67 & $-0.023^{* * *}$ & -3.36 & -0.001 & -0.59 & -0.001 & -0.59 \\
\hline Offshoring $\times$ high skilled blue collar & $-0.028^{* * *}$ & -3.22 & $-0.031^{* * *}$ & -3.50 & 0.001 & 0.44 & 0.001 & 0.41 \\
\hline Offshoring $\times$ low skilled blue collar & $-0.038^{* * *}$ & -4.36 & $-0.041^{* * *}$ & -4.59 & 0.000 & 0.05 & 0.000 & 0.00 \\
\hline Fixed effect industry & no & & yes & & no & & yes & \\
\hline Fixed effect year & yes & & yes & & yes & & yes & \\
\hline Fixed effect state & yes & & yes & & yes & & yes & \\
\hline $\mathrm{R}^{2}$ - within & 0.041 & & 0.042 & & 0.025 & & 0.026 & \\
\hline No. of obs & 69,011 & & 69,011 & & 69,011 & & 69,011 & \\
\hline
\end{tabular}

Notes: i) Source: GSOEP 2000-2013 waves; ii) ${ }^{* * *}$ denotes significant at the $1 \%$ level, ${ }^{* *}$ denotes significant at the 5\% level; * denotes significant at the $10 \%$ level; iii) The results are controlling for contract duration, age, tenure, working hours, schooling, number of adults and children, marital and health status; iv) The reference individual has a permanent contract, is married, is a high skill white collar worker, has a good health status, average income, age, tenure, hours of work, years of schooling, number of adults and children at home and is exposed to average offshoring levels.

Table 5. Job satisfaction and offshoring, by activity

\begin{tabular}{|c|c|c|c|c|c|c|c|c|}
\hline & \multicolumn{4}{|c|}{ Manufacturing } & \multicolumn{4}{|c|}{ Services } \\
\hline & \multicolumn{2}{|c|}{ Model 2a } & \multicolumn{2}{|c|}{ Model 2b } & \multicolumn{2}{|c|}{ Model 2a } & \multicolumn{2}{|c|}{ Model 2b } \\
\hline & coefficient & $\mathrm{t}$ & coefficient & $\mathrm{t}$ & coefficient & $\mathrm{t}$ & coefficient & $\mathrm{t}$ \\
\hline Ln(Income) & $0.058^{* *}$ & 1.82 & $0.059^{* *}$ & 1.85 & $0.136^{* * *}$ & 6.15 & $0.135^{* * *}$ & 6.10 \\
\hline Offshoring & -0.131 & -1.03 & $-0.160^{* *}$ & -2.02 & 0.019 & 0.54 & -0.012 & -1.08 \\
\hline Offshoring $\times$ low skilled white collar & -0.009 & -0.69 & $-0.022^{* * *}$ & -3.23 & $-0.024^{* *}$ & -2.32 & $-0.024^{* *}$ & -2.26 \\
\hline Offshoring $\times$ high skilled blue collar & -0.012 & -0.98 & $-0.033^{* * *}$ & -3.67 & $-0.037^{* *}$ & -2.03 & $-0.041^{* *}$ & -2.21 \\
\hline Offshoring $\times$ low skilled blue collar & $-0.025^{* *}$ & -1.98 & $-0.042^{* * *}$ & -4.66 & $-0.049^{* * *}$ & -2.88 & $-0.052^{* * *}$ & * -2.99 \\
\hline Fixed effect industry & no & & yes & & no & & yes & \\
\hline Fixed effect year & yes & & yes & & yes & & yes & \\
\hline Fixed effect state & yes & & yes & & yes & & yes & \\
\hline $\mathrm{R}^{2}$ - within & 0.049 & & 0.049 & & 0.036 & & 0.036 & \\
\hline No. of obs & 26,917 & & 26,917 & & 42,816 & & 42,816 & \\
\hline
\end{tabular}

Notes: i) Source: GSOEP 2000-2013 waves; ii) ${ }^{* * *}$ denotes significant at the $1 \%$ level, ${ }^{* *}$ denotes significant at the $5 \%$ level; " denotes significant at the $10 \%$ level; iii) The results are controlling for contract duration, age, tenure, working hours, schooling, number of adults and children, marital and health status; iv) The reference individual has a permanent contract, is married, is a high skill white collar worker, has a good health status, average income, age, tenure, hours of work, years of schooling, number of adults and children at home and is exposed to average offshoring levels. 
Table 6. Job insecurity and offshoring, by activity

\begin{tabular}{|c|c|c|c|c|c|c|c|c|}
\hline & \multicolumn{4}{|c|}{ Manufacturing } & \multicolumn{4}{|c|}{ Services } \\
\hline & \multicolumn{2}{|c|}{ Model 2a } & \multicolumn{2}{|c|}{ Model 2b } & \multicolumn{2}{|c|}{ Model 2a } & \multicolumn{2}{|c|}{ Model 2b } \\
\hline & coefficient & $\mathrm{t}$ & coefficient & $\mathrm{t}$ & coefficient & $\mathrm{t}$ & coefficient & $\mathrm{t}$ \\
\hline Ln(Income) & -0.013 & -0.96 & -0.013 & -0.98 & -0.007 & -0.86 & -0.007 & -0.86 \\
\hline Offshoring & 0.044 & 1.39 & 0.046 & 1.38 & 0.022 & 1.59 & 0.008 & 0.39 \\
\hline Offshoring $\times$ low skilled white collar & -0.003 & -0.50 & -0.003 & -0.51 & -0.002 & -0.60 & -0.002 & -0.57 \\
\hline Offshoring $\times$ high skilled blue collar & -0.004 & -0.77 & -0.004 & -0.79 & 0.001 & 0.20 & 0.001 & 0.09 \\
\hline Offshoring $\times$ low skilled blue collar & -0.001 & -0.27 & -0.001 & -0.26 & -0.002 & -0.30 & -0.002 & -0.25 \\
\hline Fixed effect industry & no & & yes & & no & & yes & \\
\hline Fixed effect year & yes & & yes & & yes & & yes & \\
\hline Fixed effect state & yes & & yes & & yes & & yes & \\
\hline $\mathrm{R}^{2}$ - within & 0.048 & & 0.048 & & 0.024 & & 0.024 & \\
\hline No. of obs & 26,917 & & 26,917 & & 42,816 & & 42,816 & \\
\hline
\end{tabular}

Notes: i) Source: GSOEP 2000-2013 waves; ii) ${ }^{* * *}$ denotes significant at the $1 \%$ level, ${ }^{* *}$ denotes significant at the $5 \%$ level; " denotes significant at the $10 \%$ level; iii) The results are controlling for contract duration, age, tenure, working hours, schooling, number of adults and children, marital and health status; iv) The reference individual has a permanent contract, is married, is a high skill white collar worker, has a good health status, average income, age, tenure, hours of work, years of schooling, number of adults and children at home and is exposed to average offshoring levels.

Third, we inspect the relation between offshoring, workers' categories and temporary contracts. There are reasons to believe that workers with fixed-term contracts are affected differently by offshoring than workers with permanent contracts. Temporary workers are frequently used as a channel to buffer negative economic shocks. They are more prone to see their labour market position worsen following a shock, and they have a weaker bargaining position than permanent workers do. Hence, they might face stronger JS and JI variations in case employers adjust to globalization pressure. To explore this issue, we expand our specification to allow for interactions between offshoring, temporary contracts and workers' categories. This specification allows us not only to test whether offshoring affects differently workers with a temporary contract, but also to examine to what extent the differences across workers' categories reported in the paper can be due to the unequal prevalence of temporary contracts among the different categories. Results displayed in Table 7 reject this hypothesis. We do not find significant differences among temporary and permanent workers regarding the offshoring effect. This result applies to the four categories of workers considered in the analysis, and for the two dependent variables considered in the regressions. The only significant effect corresponds to the differential effect of offshoring among low skill blue-collar workers with a temporary contract when accounting for job insecurity. In this group, the effects of offshoring are negative, although the coefficient is significant only at the $10 \%$ level.

Fourth, offshoring intensity is not constant over time and may be subject to macroeconomic shocks. Moreover, the effects of offshoring intensity upon workers' life and job conditions may differ over the economic cycle. ${ }^{10}$ If increases in globalization pressure worsen worker's employment opportunities, bargaining power and turnover rates, it is likely that these effects are

10 We thank an anonymous referee for this valuable insight. 
Economics: The Open-Access, Open-Assessment E-Journal 14 (2020-23)

Table 7. Job satisfaction, job insecurity, offshoring and temporary contracts

\begin{tabular}{|c|c|c|c|c|c|c|c|c|}
\hline & \multicolumn{4}{|c|}{ Job satisfaction } & \multicolumn{4}{|c|}{ Job insecurity } \\
\hline & \multicolumn{2}{|c|}{ Model 2a } & \multicolumn{2}{|c|}{ Model 2b } & \multicolumn{2}{|c|}{ Model 2a } & \multicolumn{2}{|c|}{ Model 2b } \\
\hline & coefficient & $\mathrm{t}$ & coefficient & $\mathrm{t}$ & coefficient & $\mathrm{t}$ & coefficient & $\mathrm{t}$ \\
\hline$\overline{\operatorname{Ln}(\text { Income })}$ & 0.128 ** & 9.49 & $0.131^{* * *}$ & 9.67 & 0.006 & 1.08 & 0.005 & 0.99 \\
\hline Temporary & 0.004 & 0.08 & 0.016 & -0.31 & $0.133^{* * *}$ & 6.68 & $0.135^{* *}$ & * 6.72 \\
\hline Offshoring & 0.013 & 0.81 & -0.022 & -0.73 & 0.006 & 1.05 & -0.006 & -0.57 \\
\hline Offshoring $\times$ crisis & $-0.063^{* *}$ & $*-5.10$ & $-0.060^{* * *}$ & -4.88 & $0.023^{* * *}$ & 5.05 & $0.023^{* *}$ & * 4.97 \\
\hline Offshoring $\times$ temporary & -0.007 & -0.29 & 0.006 & 0.24 & 0.000 & -0.05 & -0.001 & -0.12 \\
\hline Offshoring $\times$ temporary $\times$ crisis & 0.014 & 1.22 & 0.012 & 1.07 & -0.012 & -0.88 & -0.012 & -0.86 \\
\hline Offshoring $\times$ low skilled white collar & $-0.024^{* *}$ & -3.57 & $-0.021^{* * *}$ & -3.20 & -0.001 & -0.53 & -0.001 & -0.58 \\
\hline Offshoring $\times$ high skilled blue collar & $-0.032^{* *}$ & -3.75 & $-0.036^{* * *}$ & -4.15 & 0.001 & 0.27 & 0.001 & 0.31 \\
\hline Offshoring $\times$ low skilled blue collar & $-0.040^{* *}$ & -4.59 & $-0.042^{* * *}$ & -4.82 & 0.000 & 0.12 & 0.000 & 0.05 \\
\hline Control for crisis period & yes & & yes & & yes & & yes & \\
\hline Fixed effect industry & no & & yes & & no & & yes & \\
\hline Fixed effect year & yes & & yes & & yes & & yes & \\
\hline Fixed effect state & yes & & yes & & yes & & yes & \\
\hline $\mathrm{R}^{2}$ - within & 0.041 & & 0.042 & & 0.026 & & 0.026 & \\
\hline No. of obs & 69,733 & & 69,733 & & 69,733 & & 69,733 & \\
\hline
\end{tabular}

Notes: i) Source: GSOEP 2000-2013 waves; ii) ${ }^{* * *}$ denotes significant at the $1 \%$ level, ${ }^{* *}$ denotes significant at the $5 \%$ level; * denotes significant at the $10 \%$ level; iii) The results are controlling for contract duration, age, tenure, working hours, schooling, number of adults and children, marital and health status; iv) The reference individual has a permanent contract, is married, is a high skill white collar worker, has a good health status, average income, age, tenure, hours of work, years of schooling, number of adults and children at home and is exposed to average offshoring levels.

more intense during economic downturns. In Figure 1, we depict the evolution of the offshoring variable over the sample period, discriminating between manufacturing and services activities. Offshoring intensity i) rose over the period, at an average yearly rate of $1.9 \%$; ii) this increase was slightly higher in services activities (2.0\%) than in manufacturing activities (1.8\%); iii) increased at a higher rate during the pre-crisis (2000-2007) period than during the crisis (20082013) period (2.5\% against $1.1 \%$ in yearly terms).

To explore whether these variations affect workers differently depending on the economic cycle, we define a dummy variable that takes value one if the yearly observation corresponds to the crisis period (2008-2013) and zero otherwise, and interact this variable with offshoring intensity and temporary contracts. ${ }^{11}$ This full set of interactions terms allows us to examine whether the effects of offshoring are more intense during critical periods and whether temporary workers are more or less sensitive to this cyclical effect. The results, reported in Table 8, show that even after including industry controls, JS is more sensitive to offshoring intensity during an economic crisis. This is an interesting result, insofar as it suggests that the offshoring-JS relationship is asymmetric and dependent upon the business cycle. This notion is confirmed by the last two columns of Table 8. These show that increases in offshoring intensity affect JI negatively during economic declines. We interpreted the benchmark estimates reported in the previous section as evidence that offshoring shocks do not lead to job separations, and

11 A more restricted crisis period, 2008-2010, when average Germany’s GDP growth rate was relatively lower, produced similar results. These estimations are available upon request. 
Figure 1. Evolution of offshoring intensity between 2000 and 2013

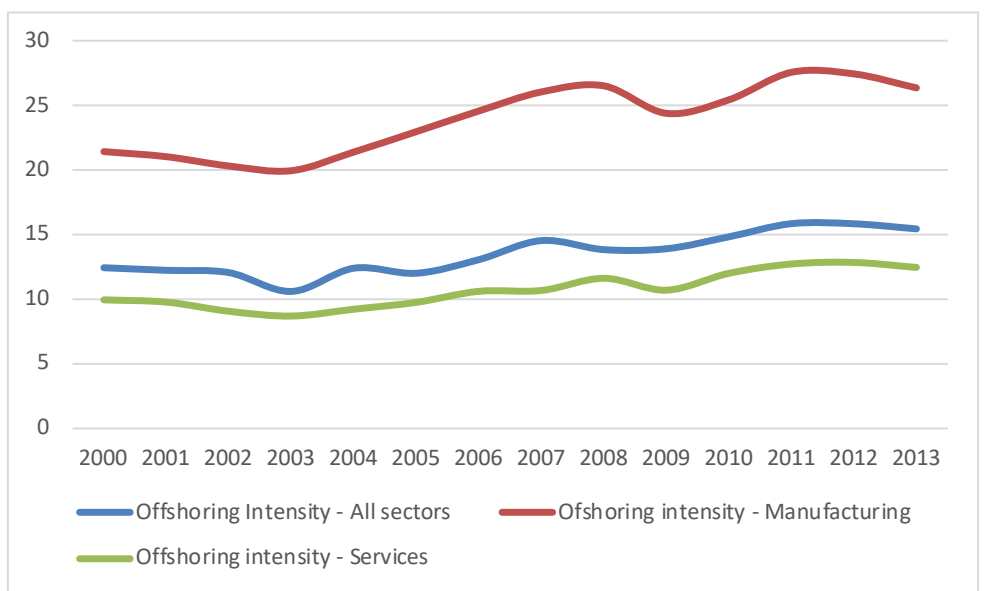

Source: German SOEP 2000-2013 waves and own calculations

suggested that workers performing offshorable tasks may suffer from wage cuts instead of job separations. However, the results in Table 8 indicate that this is only the case during recovery periods or, in other words, that offshoring shocks during economic declines are perceived as a real threat by workers.

Table 8. Job satisfaction, job insecurity, offshoring and economic crisis

\begin{tabular}{|c|c|c|c|c|c|c|c|c|}
\hline & \multicolumn{4}{|c|}{ Job satisfaction } & \multicolumn{4}{|c|}{ Job insecurity } \\
\hline & \multicolumn{2}{|c|}{ Model 2a } & \multicolumn{2}{|c|}{ Model 2b } & \multicolumn{2}{|c|}{ Model 2a } & \multicolumn{2}{|c|}{ Model 2b } \\
\hline & coefficient & $\mathrm{t}$ & coefficient & $\mathrm{t}$ & coefficient & $\mathrm{t}$ & coefficient & $\mathrm{t}$ \\
\hline Ln(Income) & $0.128^{* *}$ & 9.49 & $0.131^{* * *}$ & 9.67 & 0.006 & 1.08 & 0.005 & 0.99 \\
\hline Temporary & 0.004 & 0.08 & 0.016 & -0.31 & $0.133^{* * *}$ & 6.68 & $0.135^{* * *}$ & $* 6.72$ \\
\hline Offshoring & 0.013 & 0.81 & -0.022 & -0.73 & 0.006 & 1.05 & -0.006 & -0.57 \\
\hline Offshoring $\times$ crisis & $-0.063^{* *}$ & -5.10 & $-0.060^{* * *}$ & -4.88 & $0.023^{* * *}$ & 5.05 & $0.023^{* *}$ & $* * 4.97$ \\
\hline Offshoring $\times$ temporary & -0.007 & -0.29 & 0.006 & 0.24 & 0.000 & -0.05 & -0.001 & -0.12 \\
\hline Offshoring $\times$ temporary $\times$ crisis & 0.014 & 1.22 & 0.012 & 1.07 & -0.012 & -0.88 & -0.012 & -0.86 \\
\hline Offshoring $\times$ low skilled white collar & $-0.024^{* *}$ & -3.57 & $-0.021^{* * *}$ & -3.20 & -0.001 & -0.53 & -0.001 & -0.58 \\
\hline Offshoring $\times$ high skilled blue collar & $-0.032^{* *}$ & -3.75 & $-0.036^{* * *}$ & -4.15 & 0.001 & 0.27 & 0.001 & 0.31 \\
\hline Offshoring $\times$ low skilled blue collar & $-0.040^{* *}$ & -4.59 & $-0.042^{* * *}$ & -4.82 & 0.000 & 0.12 & 0.000 & 0.05 \\
\hline Control for crisis period & yes & & yes & & yes & & yes & \\
\hline Fixed effect industry & no & & yes & & no & & yes & \\
\hline Fixed effect year & yes & & yes & & yes & & yes & \\
\hline Fixed effect state & yes & & yes & & yes & & yes & \\
\hline $\mathrm{R}^{2}$ - within & 0.041 & & 0.042 & & 0.026 & & 0.026 & \\
\hline No. of obs & 69,733 & & 69,733 & & 69,733 & & 69,733 & \\
\hline
\end{tabular}

Notes: i) Source: GSOEP 2000-2013 waves; ii) ${ }^{* * *}$ denotes significant at the $1 \%$ level, ${ }^{* *}$ denotes significant at the $5 \%$ level; ${ }^{*}$ denotes significant at the $10 \%$ level; iii) The results are controlling for contract duration, age, tenure, working hours, schooling, number of adults and children, marital and health status; iv) The reference individual has a permanent contract, is married, is a high skill white collar worker, has a good health status, average income, age, tenure, hours of work, years of schooling, number of adults and children at home and is exposed to average offshoring levels. 
Table 9. Job satisfaction, job insecurity and offshoring, by gender

\begin{tabular}{|c|c|c|c|c|c|c|c|c|}
\hline & \multicolumn{4}{|c|}{ Job satisfaction } & \multicolumn{4}{|c|}{ Job insecurity } \\
\hline & \multicolumn{2}{|l|}{ Men } & \multicolumn{2}{|l|}{ Women } & \multicolumn{2}{|c|}{ Men } & \multicolumn{2}{|c|}{ Women } \\
\hline & coefficient & $\mathrm{t}$ & coefficient & $\mathrm{t}$ & coefficient & $\mathrm{t}$ & coefficient & $\mathrm{t}$ \\
\hline Ln(Income) & $0.137^{* *}$ & 7.21 & $0.133^{* * *}$ & 6.84 & 0.001 & 0.16 & 0.005 & 0.63 \\
\hline Offshoring & -0.003 & -0.07 & -0.028 & -0.66 & 0.001 & 0.03 & -0.002 & -0.16 \\
\hline Offshoring $\times$ low skilled white collar & $-0.023^{* *}$ & -2.26 & $-0.023^{* *}$ & -2.48 & -0.008 & -0.66 & 0.003 & 0.79 \\
\hline Offshoring $\times$ high skilled blue collar & $-0.028^{* *}$ & $* * * 2.92$ & $-0.083^{* * *}$ & -4.00 & 0.000 & -0.11 & 0.005 & 0.66 \\
\hline Offshoring $\times$ low skilled blue collar & $-0.034^{* *}$ & $* * 3.25$ & $-0.066^{* * *}$ & -4.05 & -0.002 & -0.50 & 0.003 & 0.46 \\
\hline Fixed effect industry & yes & & yes & & yes & & yes & \\
\hline Fixed effect year & yes & & yes & & yes & & yes & \\
\hline Fixed effect state & yes & & yes & & yes & & yes & \\
\hline $\mathrm{R}^{2}$ - within & 0.044 & & 0.049 & & 0.036 & & 0.036 & \\
\hline No. of obs & 36,483 & & 33,250 & & 36,483 & & 33,250 & \\
\hline
\end{tabular}

Notes: i) Source: GSOEP 2000-2013 waves; ii) ${ }^{* * *}$ denotes significant at the $1 \%$ level, ${ }^{* *}$ denotes significant at the $5 \%$ level; ${ }^{*}$ denotes significant at the $10 \%$ level; iii) The results are controlling for contract duration, age, tenure, working hours, schooling, number of adults and children, marital and health status; iv) The reference individual has a permanent contract, is married, is a high skill white collar worker, has a good health status, average income, age, tenure, hours of work, years of schooling, number of adults and children at home and is exposed to average offshoring levels.

The results in Table 8 also confirm the previous finding that there are no significant differences among temporary and permanent workers regarding the offshoring effect, even after controlling for the economic cycle. The fact that the effect of offshoring upon JS differs among the different categories of workers is also robust to the inclusion of controls for the economic cycle.

Our fifth robustness check consists in presenting separate results by gender to examine whether men and women are affected to different extents by offshoring. The results in Table 9 correspond to the model with the full set of industry controls (2b). We do not find remarkable differences across genders. The results confirm substantial heterogeneity among the different categories of workersin response to, with high skilled white collars being the unique category unaffected by offshoring regardless of the gender. Still, we find that differences across categories of workers are larger among women, with women in blue-collar occupations being more severely affected by offshoring activities. In terms of JI, the results are almost identical across genders and broadly supportive of the general result that JI is not dependent upon offshoring activities.

Finally, the large sets of controls and fixed effects included in Models $1 \mathrm{~b}$ and $2 \mathrm{~b}$ substantially mitigate concerns with omitted variables. Still, the results may be misleading if workers sort across industries based on their JS or JI and in anticipation changes in the offshoring intensity. If workers less satisfied with their jobs or more insecure at their jobs sort into less trade exposed industries, then the estimates reported so far would be downward biased; the opposite sorting pattern would instead induce an upward bias. To shed light on the patterns and implications of worker sorting, we examine industry switching in our data. In a given year, approximately $15 \%$ of workers change for a job in another industry, and only $50.7 \%$ of individuals remain always in the same industry. We start by studying whether industry switching is correlated with changes in offshoring intensity. To this purpose, for each worker, 
we compute the year-to-year change in offshoring intensity $(\Delta \mathrm{O})$, based on her industries of employment at $t$ and $t-1$. For industry stayers, $\Delta \mathrm{O}$ only reflects variation in offshoring intensity within the same industry, whereas for industry switchers it captures the additional change due to the switch. Then, we regress $\Delta \mathrm{O}$ on a dummy equals to 1 for workers who always remain in the same industry ('stayers'). The results are reported in the first column of Table 10. We find a small and not statistically significant coefficient, suggesting that a worker who switches industry does not experience a significantly different change in offshoring intensity compared to a worker who remains in the same industry. Next, we look for differential patterns of correlation between $\Delta \mathrm{O}$ and the lag value of JS for stayers and switchers separately. The next columns of Table 10 show virtually no relation between the two variables, for any group of workers. In other words, industry switching is largely independent of the interplay between JS and changes in offshoring intensity. In the last two columns, we proceed likewise with JI. In this case, JI at time $t-1$ does not predict $\Delta \mathrm{O}$ at time $\mathrm{t}$ among switchers. Therefore, we must reject the hypothesis that workers that are more insecure sort into industries with less offshoring intensity. Still, the coefficient among stayers is statistically significant, a result that suggests that reported JI may reflect anticipation effects related with future increasing offshoring.

Table 10. Cross-industry sorting, offshoring, job satisfaction and job insecurity

\begin{tabular}{|c|c|c|c|c|c|c|c|c|c|c|}
\hline & \multicolumn{2}{|c|}{ All sample } & \multicolumn{2}{|c|}{ Stayers } & \multicolumn{2}{|c|}{ Switchers } & \multicolumn{2}{|l|}{ Stayers } & \multicolumn{2}{|c|}{ Switchers } \\
\hline & coefficient & $\mathrm{t}$ & coefficient & $\mathrm{t}$ & coefficient & $\mathrm{t}$ & coefficient & $\mathrm{t}$ & coefficient & $\mathrm{t}$ \\
\hline Stayer & 0.005 & 1.37 & & & & & & & & \\
\hline $\mathrm{JS}_{\mathrm{t}-1}$ & & & -0.002 & -1.000 & 0.000 & 0.100 & & & & \\
\hline $\mathrm{JI}_{\mathrm{t}-1}$ & & & & & & & $0.013^{* *}$ & 2.070 & -0.002 & -0.310 \\
\hline$R^{2}$ & 0.025 & & 0.000 & & 0.000 & & 0.000 & & 0.000 & \\
\hline No. of obs & 30,939 & & 13,601 & & 17,079 & & 13,601 & & 17,079 & \\
\hline
\end{tabular}

Notes: i) Source: GSOEP 2000-2013 waves; ii) ** denotes significant at the 5\% level.

\section{Conclusions}

This paper examines the link between offshoring, job satisfaction and job insecurity. The results are based on micro data from the 2000-2013 waves of the German Socioeconomic Panel (GSOEP) and information from the Trade in Value Added (TiVA) database from the OCDE. Merging the two datasets using industry as matching criterion allowed us to estimate a set of JS and JI equations where the offshoring intensity within the industry where the individual works was the crux of our analysis.

Offshoring was found to be negatively associated with JS. This effect differed among categories of workers, with high skill white-collar workers being mostly unaffected by offshoring and low skill blue-collar workers exhibiting the largest negative effects. These differences and the offshoring effect were found to be relatively larger in manufacturing industries. 
The results also indicate that offshoring intensity is not significantly associated with increased JI, a results that holds for all workers' categories. Discriminating between manufacturing and services activities, we found that the extent of heterogeneity and the offshoring effect is relatively larger in manufacturing industries. We also found that the effect of offshoring intensity upon job satisfaction is more negative and significant in periods of economic decline. In fact, increases in offshoring intensity can lead to significantly higher job risks during periods of economic decline.

Our conjecture for this result is that offshoring may induce restructuration and changes at the job level that are quite demanding for workers and affect job satisfaction. However, these changes may guarantee the future of the jobs in a convincing manner, maintaining the prospects of unemployment unaltered.

The paper's main findings were robust to several sensitivity checks. We found no significant differences among temporary and permanent workers regarding the offshoring effect, meaning that in our data the consequences of offshoring are not related with the personal risk of losing the job but with the overall perception of the internationalization of the sector and its consequences on unobserved job conditions. We also examined to what extent worker sort across industries based on their previous JS or JI and in anticipation of changes in the offshoring intensity. Workers' sorting could bias the estimates of offshoring downwards. Offshoring does not seem to affect worker sorting.

Previous research has found small but significant effects of trade exposure on unemployment transitions (Bachmann and Braun, 2011, Görg and Görlich, 2012, Görg and Görlich, 2015). The divergence with our results mays be explained by the fact that we rely on the job insecurity perceived by workers, and not on objective labour market transitions. In fact, this divergence may be indicative of two things. Firstly, objective indicators may be poorly related to workers' perceptions, insofar as workers have first-hand information regarding their personal conditions, intentions and motivations. Individuals may not process objective transitions to unemployment as a realized risk if the individual has anticipated the event, or if it occurred due to decisions consciously taken by the individual. Secondly, despite having privileged information about their personal life and conditions, individuals may be unaware of the events at the firm, regional and country level that affect their true unemployment probability. Personal wellbeing is well known as being more dependent on ex-ante individual perceptions than on ex-ante objective hazards. In terms of public support to free trade, or wage bargaining, what arguably matters most are subjective concerns about job security. This is a question for future research is to test for explanations that can reconcile the results under the objective and the subjective approach.

From a policy point of view, our findings support partially the notion that globalisation would be a source of important dissatisfaction and negative feelings at the workplace, at least for German workers. Even if offshoring is not perceived as increasing job loss risks, low skill blue-collar workers feel less satisfied at their job when offshoring increases. In the absence of more accurate information about climate at the workplace, we observe that JS deteriorates with offshoring even if it does not translate into a perception of job loss risk. The fact that low skilled, and in particular blue-collar workers, are more affected by offshoring calls for a need of policies that facilitate the adaptation of this group. In this respect, the promotion of training 
policies oriented towards the acquisition of skills and credentials that are valuable at the international level could be of special importance.

Whether our results can be safely extrapolated to other countries depends on various considerations. It seems clear that the functioning of the labour market in European countries is clearly different from the US (Liu and Trefler, 2011, Baumgarten, 2015). Savsin and Akay (2020) explicitly compare the effects of offshoring on well-being measures obtained for Germany with the ones obtained for similar time periods for the UK and Australia, and find similar results. According to TIVA (2016), the magnitude of offshoring among Germany and other European countries is comparable: Foreign value added in exports represented in 2000 and in 2011 respectively, 20.1\% and 25.6\% in Germany, 23.2\% and 27.6\% in EU-15 and 23.6 and 28.4 in EU-28. Under the light of Crinó's (2009) survey, it is difficult to compare national results because of different methodologies in the relevant measures but, overall, the effects reported in Europe tend to go in the same direction even if the magnitude of the effects differs by country.

Our research could be extended in several directions. A promising avenue would be to distinguish among destinations of offshoring. In a paper very related to ours, Geishecker et al (2012) find that offshoring to low-wage countries raises job loss fears whilst offshoring towards high-wage countries reduces job loss fears, the two effects being very similar in magnitude. Similarly, we found evidence to suggest that the JS of individuals working in manufacturing activities is more sensitive to offshoring intensity than the JS of workers from the service sector. However, service offshoring is growing, especially in business services that complement the fabrication process of manufacturing products. These complex changes deserve further attention. Finally, our approximation of workers' categories could also be refined to take into account the nature of the tasks performed and to what extent they are offshorable.

Acknowledgement Santiago Budría gratefully acknowledges the financial support provided by the R\&D Program in Social Sciences and Humanities by the Autonomous Community of Madrid, OPINBI project (Ref: H2019/HUM-5793). Juliette Milgram thanks the financial support from SEJ 340 projects of the Junta de Andalucía and PGC2018-093506-B-I00 from Ministerio de Ciencia, Innovación y universidades (Spain). 


\section{References}

Autor, D.H., Dorn, D., and Hanson, G.H. (2013). The China Syndrome: Local labor market effects of import competition in the United States. American Economic Review 103(6), 2121-2168. https://www.aeaweb.org/articles?id=10.1257/aer.103.6.2121

Bachmann, R., Baumgarten, D., and Stiebale, J. (2014). Foreign direct investment, heterogeneous workers and employment security: Evidence from Germany. Canadian Journal of Economics/ Revue canadienne d'économique 47, 720-757. https://doi.org/10.1111/caje.12094

Bachmann, R., and Braun, S. (2011). The impact of international outsourcing on labour market dynamics in Germany. Scottish Journal of Political Economy 58(1), 1-28. https://onlinelibrary.wiley.com/doi/abs/10.1111/j.1467-9485.2010.00535.x

Baumgarten, D. (2015). Offshoring, the nature of tasks, and occupational stability: Empirical evidence for Germany. The World Economy 38, 479-508. https://doi.org/10.1111/twec.12155

Baumgarten, D., Geishecker, I., and Görg, H. (2013). Offshoring, tasks, and the skill-wage pattern. European Economic Review 61, 132-152. https://ideas.repec.org/a/eee/eecrev/v61y2013icp132-152.html

Becker, S.O., Ekholm, K., and Muendler, M. (2013). Offshoring and the onshore composition of tasks and skills. Journal of International Economics 90, 91-106.

Blinder, A.S. (2006). Offshoring: The next industrial revolution? Foreign Affairs, March-April 2006, 85(2), 113-128.

https://www.foreignaffairs.com/articles/2006-03-01/offshoring-next-industrial-revolution

Brändle, T., Koch, A. (2015). Offshoreability and wages. Evidence from German task data. Economia e Politica Industriale, volume, 42: 189. https://doi.org/10.1007/s40812-014-0004-z

Burgard, S.A., Brand, J., and House, J.S. (2009). Perceived job insecurity and worker health in the United States. Social Science and Medicine 69, 777-785. https://pubmed.ncbi.nlm.nih.gov/19596166/

Casabianca, E.J., Lo Turco, A., and Pigini, C. (2019). Import penetration and returns to tasks: Recent evidence from the Peruvian labour market, Empirical Economics 56, 551. https://doi.org/10.1007/s00181-017-1412-5

Consoli, D., Vona, F., and Rentocchini, F. (2016). That was then, this is now: Skills and routinization in the 2000s, Industrial and Corporate Change 25(5), 847-866. https://doi.org/10.1093/icc/dtw030

Crinò, R. (2009). Offshoring, multinationals and labour market: A review of the empirical literature. Journal of Economic Surveys 23, 197-249. https://doi.org/10.1111/j.1467-6419.2008.00561.x

Crozet M., and Orefice G. (2017). Trade and labor market: What do we know? CEPII Policy Brief 201715, 2017 , CEPII. http://www.cepii.fr/CEPII/fr/publications/pb/abstract.asp?NoDoc=10063 
Daudin, G., Rifflart, C., and Schweisguth, D. (2011). Who produces for whom in the world economy? Canadian Journal of Economics/Revue canadienne d'économique 44(4), 1403-1437. https://onlinelibrary.wiley.com/doi/abs/10.1111/j.1540-5982.2011.01679.x

Ebenstein, A., Harrison, A., McMillan, M., and Phillips, S. (2014). Estimating the impact of trade and offshoring on American workers using the current population survey. Review of Economics and Statistics 96(4), 581-595. https://ideas.repec.org/a/tpr/restat/v96y2014i4p581-595.html

Feenstra, R.C., Ma, H., Xu, Y. (2019). US exports and employment. Journal of International Economics, 120, 46-58. https://doi.org/10.1016/j.jinteco.2019.05.002

Ferrer-i-Carbonell, A. (2013). Happiness economics, SERIEs, 4, 35-60. https://link.springer.com/article/10.1007/s13209-012-0086-7

Ferrer-i-Carbonell, A., and Frijters, P. (2004). How important is methodology for the estimates of the determinants of happiness? Economic Journal 114, 641-659.

https://econpapers.repec.org/article/ecjeconjl/v_3a114_3ay_3a2004_3ai_3a497_3ap_3a641659.htm

Geishecker, I. (2008). The impact of international outsourcing on individual employment security: A micro-level analysis. Labour Economics, 15, 291-314.

https://doi.org/10.1016/j.labeco.2007.06.015

Geishecker, I., Riedl, M., and Frijters, P. (2012). Offshoring and job loss fears: An econometric analysis of individual perceptions, Labour Economics 19, 738-747.

https://econpapers.repec.org/article/eeelabeco/v_3a19_3ay_3a2012_3ai_3a5_3ap_3a738-747.htm

Görg, H., and Görlich, D. (2015). Offshoring, wages and job security of temporary worker, Review of World Economics 151, 533-554.

https://www.ifw-kiel.de/publications/journal-article/offshoring-wages-and-job-security-oftemporary-workers-8264/

Görg, H., and Görlich, D. (2012). Trade and labour market outcomes, in OECD, Policy priorities for international trade and jobs, Chapter 6, OECD: OECD Publishing.

Grossman, G.M., and Rossi-Hansberg, E. (2008). Trading tasks: A simple theory of offshoring, American Economic Review, 98(5), 1978-97.

https://www.aeaweb.org/articles?id=10.1257/aer.98.5.1978

Grossman, G.M., and Rossi-Hansberg, E. (2006). Trading tasks: A simple theory of offshoring. National Bureau of Economic Research Working Paper 12721.

https://ideas.repec.org/p/nbr/nberwo/12721.html

Hogrefe, J., and Yao, Y., (2016). Offshoring and labor ncome risk: an empirical investigation. Empirical Economics, 50(3), 1045-1063, https://econpapers.repec.org/article/sprempeco/v_3a50_3ay_3a2016_3ai_3a3_3ad_3a10.1007_5fs 00181-015-0966-3.htm

Huber, K., and Winkler, E. (2019). All you need is love? Trade shocks, inequality, and risk sharing between partners. European Economic Review, 111, 305-335.

https://ideas.repec.org/a/eee/eecrev/v111y2019icp305-335.html 
Hummels D, Jørgensen R,Munch JR, Xiang C (2014). The wage effects of offshoring: Evidence from Danish matched worker-firm data. American Econonomc Review 104(6):1597-1629. https://doi.org/10.1257/aer.104.6.1597

Hummels, D., Munch, J.R, and Xiang, C. (2018). Offshoring and labor markets. Journal of Economic Literature 56 (3), 981-1028. https://econpapers.repec.org/article/aeajeclit/v_3a56_3ay_3a2018_3ai_3a3_3ap_3a981-1028.htm

Jahn, E. (2015). Don’t worry, be flexible? - Job satisfaction among flexible workers. Australian Journal of Labour Economics 18(2), 147. https://econpapers.repec.org/article/ozljournl/v_3a18_3ay_3a2015_3ai_3a2_3ap_3a147-168.htm

Johnson, R.C., and Noguera, G. (2012). Accounting for intermediates: Production sharing and trade in value added. Journal of International Economics 86(2), 224-236. https://econpapers.repec.org/article/eeeinecon/v_3a86_3ay_3a2012_3ai_3a2_3ap_3a224-236.htm

Khun, C., Lahiri, S., and Lim, S. (2015). Do people really support trade restrictions? Cross-country evidence. The Journal of International Trade \& Economic Development 24(1), 132-146. https://econpapers.repec.org/article/tafjitecd/v_3a24_3ay_3a2015_3ai_3a1_3ap_3a132-146.htm

Koopman, R., Wang, Z., and Wei, S.-J. (2014). Tracing value-added and double counting in gross exports. American Economic Review 104(2), 459-494. https://www.aeaweb.org/articles?id=10.1257/aer.104.2.459

László, K., Pikhart, H., Kopp, M., Bobak, M., Pajak, A., Malyutina, S., Salavecz, G., and Marmot, M. (2010). Job insecurity and health: A study of 16 European countries. Social Science and Medicine 70, 867-874. https://www.ncbi.nlm.nih.gov/pmc/articles/PMC2845821/

Liu, R., Trefler, D. (2019). A sorted tale of globalization: White collar jobs and the rise of service offshoring, Journal of International Economics 118, 105-122. https://doi.org/10.1016/j.jinteco.2018.11.004.

Lo Turco, A., Maggioni, D., and Picchio, M. (2013). Offshoring and job stability: Evidence from Italian manufacturing, Structural Change and Economic Dynamics 26, 27-46. https://doi.org/10.1016/j.strueco.2013.04.001.

Lurweg, M. (2010). Perceived job insecurity, unemployment risk and international trade: A micro-level analysis of employees in German service industries, No 32, CAWM Discussion Papers, University of Münster, Center of Applied Economic Research Münster (CAWM). https://www.wiwi.unimuenster.de/cawm/sites/cawm/files/cawm/download/Diskussionspapiere/cawm_dp32.pdf

OECD (2018). The changing nature of international production: Insights from trade in value added and related indicators. http://www.oecd.org/industry/ind/tiva-2018-flyer.pdf.

Oswald, A.J., Proto, E., and Sgroi, D. (2015). Happiness and productivity, Journal of Labor Economics 33, no. 4 (October 2015), 789-822. https://doi.org/10.1086/681096

Ottaviano, G.I. P., Peri, G., and Wright. G.C. (2013). Immigration, offshoring, and American jobs. American Economic Review 103 (5), 1925-59. https://www.aeaweb.org/articles?id=10.1257/aer.103.5.1925

Parteka, A. (2018). Import intensity of production, tasks and wages: Micro-level evidence for Poland, Entrepreneurial Business and Economics Review 2, 71-89. https://eber.uek.krakow.pl/index.php/eber/article/view/354 
Parteka, A., and Wolszczak-Derlacz, J. (2019). Global value chains and wages: Multi-country evidence from linked worker-industry data, Open Economies Review, (2019) 30, 505. https://doi.org/10.1007/s11079-018-9518-8.

Pfaffermayr, M., Egger, P., and Weber, A. (2007). Sectoral adjustment of employment to shifts in outsourcing and trade: Evidence from a dynamic fixed effects multinomial logit model. Journal of Applied Econometrics 22(3), 559-580.

https://econpapers.repec.org/article/jaejapmet/v_3a22_3ay_3a2007_3ai_3a3_3ap_3a559-580.htm

Rohde, N., Tang, K.K., Osberg, L., and Rao, P. (2017). Is it vulnerability or economic insecurity that matters for health?. Journal of Economic Behavior and Organization 134(C), 307-319. https://econpapers.repec.org/article/eeejeborg/v_3a134_3ay_3a2017_3ai_3ac_3ap_3a307-319.htm

Savsin S., and Akay A. (2020). Offshoring and mental well-being of workers, Mimeo.

Stolper, W.F., and Samuelson, P.A. (1941). Protection and real wages. The Review of Economic Studies 9(1), 58-73. https://econpapers.repec.org/article/ouprestud/v_3a9_3ay_3a1941_3ai_3a1_3ap_3a58-73.htm

Timmer, M. (2012). The world input-output database (WIOD): Contents, sources and methods (WIOD Working Paper 10). https://econpapers.repec.org/paper/lnzwpaper/20120401.htm

Timmer, M.P., Erumban, A.A., Los, B., Stehrer, R., and De Vries, G.J. (2014). Slicing up global value chains. Journal of Economic Perspectives, 28(2), 99-118. https://doi.org/10.1257/jep.28.2.99

Van Praag, B.M.S., and Ferrer-i-Carbonell, A. (2008). Happiness quantified: A satisfaction calculus approach. Oxford University Press, Revised edition. https://www.oxfordscholarship.com/view/10.1093/0198286546.001.0001/acprof-9780198286547

Wagner, G.G., J.R. Frick, and Schupp, J. (2007). The German socio-economic panel study (SOEP) scope, evolution and enhancements. Schmollers Jahrbuch 127, 139-169.

https://www.diw.de/de/diw_01.c.450791.de/publikationen/soeppapers/2007_0001/the_german_soc io-economic_panel_study_soep_scope_evolution_and_enhancements.html

Wright, G.C. (2014). Revisiting the employment impact of offshoring, European Economic Review 66, 63-83.

https://econpapers.repec.org/article/eeeeecrev/v_3a66_3ay_3a2014_3ai_3ac_3ap_3a63-83.htm 


\section{Appendix}

Table A1. Correspondence between NACE and TiVA industries.

\begin{tabular}{|c|c|c|c|}
\hline Tiva & label_tiva & nace & label_nace \\
\hline D01T03 & Agriculture, forestry and fishing & 1 & Agriculture, hunting and related service activities \\
\hline D01T03 & Agriculture, forestry and fishing & 2 & Forestry, logging and related service activities \\
\hline D01T03 & Agriculture, forestry and fishing & 5 & Fishing, operation of fish hatcheries and fish farms \\
\hline D05T06 & $\begin{array}{l}\text { Mining and extraction of energy producing } \\
\text { products }\end{array}$ & 10 & Mining of coal and lignite \\
\hline D05T06 & $\begin{array}{l}\text { Mining and extraction of energy producing } \\
\text { products }\end{array}$ & 11 & Extraction of crude petroleum and natural gas \\
\hline D09 & Mining support service activities & 12 & Mining of uranium and thorium ores \\
\hline D07T08 & $\begin{array}{l}\text { Mining and quarrying of non-energy } \\
\text { producing products }\end{array}$ & 13 & Mining of metal ores \\
\hline D07T08 & $\begin{array}{l}\text { Mining and quarrying of non-energy } \\
\text { producing products }\end{array}$ & 14 & Other mining and quarrying \\
\hline D10T12 & Food products, beverages and tobacco & 15 & Manufacture of food products and beverages \\
\hline D10T12 & Food products, beverages and tobacco & 16 & Manufacture of tobacco products \\
\hline D13T15 & $\begin{array}{l}\text { Textiles, wearing apparel, leather and } \\
\text { related products }\end{array}$ & 17 & Manufacture of textiles \\
\hline D13T15 & $\begin{array}{l}\text { Textiles, wearing apparel, leather and } \\
\text { related products }\end{array}$ & 18 & Manufacture of wearing apparel \\
\hline D13T15 & $\begin{array}{l}\text { Textiles, wearing apparel, leather and } \\
\text { related products }\end{array}$ & 19 & Tanning and dressing of leather \\
\hline D16 & Wood and products of wood and cork & 20 & $\begin{array}{l}\text { Manufacture of wood and of products of wood and } \\
\text { cork, except furniture }\end{array}$ \\
\hline D17T18 & Paper products and printing & 21 & Manufacture of pulp, paper and paper products \\
\hline D17T18 & Paper products and printing & 22 & $\begin{array}{l}\text { Publishing, printing and reproduction of recorded } \\
\text { media }\end{array}$ \\
\hline D19 & Coke and refined petroleum products & 23 & $\begin{array}{l}\text { Manufacture of coke, refined petroleum products } \\
\text { and nuclear fuel }\end{array}$ \\
\hline D20T21 & Chemicals and pharmaceutical products & 24 & Manufacture of chemicals and chemical products \\
\hline D22 & Rubber and plastic products & 25 & Manufacture of rubber and plastic products \\
\hline D23 & Other non-metallic mineral products & 26 & $\begin{array}{l}\text { Manufacture of other non-metallic mineral } \\
\text { products }\end{array}$ \\
\hline D24 & Basic metals & 27 & Manufacture of basic metals \\
\hline D25 & Fabricated metal products & 28 & $\begin{array}{l}\text { Manufacture of fabricated metal products, except } \\
\text { machinery and equipment }\end{array}$ \\
\hline D28 & Machinery and equipment, nec & 29 & Manufacture of machinery and equipment n.e.c. \\
\hline D26 & Computer, electronic and optical products & 30 & Manufacture of office machinery and computers \\
\hline D27 & Electrical equipment & 31 & $\begin{array}{l}\text { Manufacture of electrical machinery and } \\
\text { apparatus n.e.c. }\end{array}$ \\
\hline
\end{tabular}


Economics: The Open-Access, Open-Assessment E-Journal 14 (2020-23)

\begin{tabular}{|c|c|c|c|}
\hline D26 & Computer, electronic and optical products & 32 & $\begin{array}{l}\text { anufacture of radio, television and communication } \\
\text { equipment and apparatus }\end{array}$ \\
\hline D26 & Computer, electronic and optical products & 33 & $\begin{array}{l}\text { Manufacture of medical, precision and optical } \\
\text { instruments, watches and clocks }\end{array}$ \\
\hline D29 & Motor vehicles, trailers and semi-trailers & 34 & $\begin{array}{l}\text { Manufacture of motor vehicles, trailers and semi- } \\
\text { trailers }\end{array}$ \\
\hline D30 & Other transport equipment & 35 & Manufacture of other transport equipment \\
\hline D31T33 & $\begin{array}{l}\text { Other manufacturing; repair and } \\
\text { installation of machinery and equipment }\end{array}$ & 36 & Manufacture of furniture \\
\hline D31T33 & & 37 & Recycling \\
\hline D35T39 & $\begin{array}{l}\text { Electricity, gas, water supply, sewerage, } \\
\text { waste and remediation services }\end{array}$ & 40 & Electricity, gas, steam and hot water supply \\
\hline D35T39 & $\begin{array}{l}\text { Electricity, gas, water supply, sewerage, } \\
\text { waste and remediation services }\end{array}$ & 41 & Collection, purification and distribution of water \\
\hline D41T43 & Construction & 45 & ConstructionM \\
\hline D45T47 & $\begin{array}{l}\text { Wholesale and retail trade; repair of motor } \\
\text { vehicles }\end{array}$ & 50 & $\begin{array}{l}\text { Sale, maintenance and repair of motor vehicles } \\
\text { and motorcycles }\end{array}$ \\
\hline D45T47 & $\begin{array}{l}\text { Wholesale and retail trade; repair of motor } \\
\text { vehicles }\end{array}$ & 51 & $\begin{array}{l}\text { Wholesale trade and commission trade, except of } \\
\text { motor vehicles and motorcycles }\end{array}$ \\
\hline D45T47 & $\begin{array}{l}\text { Wholesale and retail trade; repair of motor } \\
\text { vehicles }\end{array}$ & 52 & $\begin{array}{l}\text { Retail trade, except of motor vehicles and } \\
\text { motorcycles }\end{array}$ \\
\hline D55T56 & Accomodation and food services & 55 & Hotels and restaurants \\
\hline D49T53 & Transportation and storage & 60 & Land transport \\
\hline D49T53 & Transportation and storage & 61 & Water transport \\
\hline D49T53 & Transportation and storage & 62 & Air transport \\
\hline D49T53D69T82 & Transportation and storage & 63 & Supporting and auxiliary transport activities \\
\hline D61 & Telecommunications & 64 & Post and telecommunications \\
\hline D64T66 & Financial and insurance activities & 65 & $\begin{array}{l}\text { Financial intermediation, except insurance and } \\
\text { pension funding }\end{array}$ \\
\hline D64T66 & Financial and insurance activities & 66 & $\begin{array}{l}\text { Insurance and pension funding, except compulsory } \\
\text { social security }\end{array}$ \\
\hline D64T66 & Financial and insurance activities & 67 & Activities auxiliary to financial intermediation \\
\hline D68 & Real estate activities & 70 & Real estate activities \\
\hline D69T82 & Other business sector services & 71 & $\begin{array}{l}\text { Renting of machinery and equipment without } \\
\text { operator and of personal and household goods }\end{array}$ \\
\hline D62T63 & IT and other information services & 72 & Computer and related activities \\
\hline D69T82 & Other business sector services & 73 & Research and development \\
\hline D69T82 & Other business sector services & 74 & Other business activities \\
\hline D84 & $\begin{array}{l}\text { Public admin. and defence; compulsory } \\
\text { social security }\end{array}$ & 75 & Public administration and defence \\
\hline D85 & Education & 80 & Education \\
\hline D86T88 & Human health and social work & 85 & Health and social work \\
\hline D35T39 & Electricity, gas, water supply, sewerage, & 90 & Sewage and refuse disposal, sanitation and similar \\
\hline
\end{tabular}


Economics: The Open-Access, Open-Assessment E-Journal 14 (2020-23)

\begin{tabular}{|l|l|l|l|}
\hline & waste and remediation services & & activities \\
\hline D90T96 & $\begin{array}{l}\text { Arts, entertainment, recreation and other } \\
\text { service activities }\end{array}$ & 91 & Activities of membership organizations n.e.c. \\
\hline D58T60D90T96 & $\begin{array}{l}\text { Publishing, audiovisual and broadcasting } \\
\text { activities }\end{array}$ & 92 & Recreational, cultural and sporting activities \\
\hline D90T96 & $\begin{array}{l}\text { Arts, entertainment, recreation and other } \\
\text { service activities }\end{array}$ & 93 & Other service activities \\
\hline D97T98 & Private households with employed persons & 95 & Private households with employed persons \\
\hline
\end{tabular}

